\title{
ADIÇÃO DE LEITE RECONSTITUÍDO NA FABRICAÇÃO DE QUEIJO MINAS FRESCAL
}

\section{LUCIANA VIRIATO SABOYA}

Engenheira Agrônoma

Orientador: Prof. Dr. ANTONIO JOAQUIM DE OLIVEIRA

Dissertação apresentada à Escola Superior de Agricultura "Luiz de Queiroz", Universidade de São Paulo, para obtenção do título de Mestre em Agronomia, Área de Concentração: Ciência e Tecnologia de Alimentos.

PIRACICA $\bar{B} A$

Estado de São Paulo - Brasil

Agosto - 1997 
Dados Internacionais de Catalogação na Publicaçāo (CIP) DIVISÁo de BIBLIOTECA E dOCUMENTAÇĀo - Campus "Luiz de Queiroz"/USP

Saboya, Luciana Viriato

Adição de leite reconstituido na fabricação de queijo Minas Frescal / Luciana Viriato Saboya. - - Piracicaba, 1997.

$82 \mathrm{p}$.

Dissertação (mestrado) -- Escola Superior de Agricultura Luiz de Queiroz, 1997. Bibliografia.

1. Laticínio 2. Leite reconstituído 3. Queijo Minas Frescal 4. Tecnologia de alimento I. Título

$\operatorname{CDD} 637.353$ 


\section{ADIÇÃO DE LEITE RECONSTITUIIDO NA FABRICAÇÃO DE QUEIJO MINAS FRESCAL}

LUCIANA VIRIATO SABOYA

Aprovada em: 12.12.97

Comissão julgadora:

Prof. Dr. Antonio Joaquim de Oliveira

ESALQ/USP

Prof. Dr. Luiz Eduardo Gutierrez

ESALQ/USP

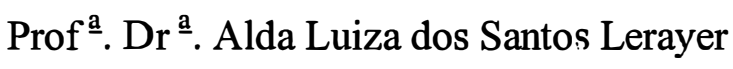

ITAL

Arace.

Prof. Dr. ANTONIOJOAQUIM DE OLIVEIRA

Orientador 
A minha melhor amiga, a quem devo tudo que hoje sou, minha mãe, Dedico

Ao meu irmão Leopoldo, Ofereço 
Àquelas pessoas que, não por obra do acaso, passaram por minha vida...

"Por um poder imortal

Todas as coisas, perto ou distante,

Ocultamente estão ligadas entre si...

E tão ligadas estão

Que não se pode tocar uma flor

Sem incomodar uma estrela..." 


\section{AGRADECIMENTOS}

À Deus Pai, pelas bênçãos de cada dia.

À Escola Superior de Agricultura "Luiz de Queiroz", em particular ao Departamento de Ciência e Tecnologia Agroindustrial pela formação profissional e acolhimento de seus funcionários e professores.

À Coordenadoria de Aperfeiçoamento do Pessoal de Ensino Superior (CAPES), pela bolsa de estudos concedida durante o curso de Mestrado.

Ao Prof. Antonio Joaquim de Oliveira, pela amizade, apoio e orientação durante a realização deste trabalho.

Ao grande mestre dos queijos, Múcio M. Furtado, pela amizade, incentivo e valiosa colaboração durante a elaboração deste trabalho.

À Leila M. Spadoti, pela enorme amizade, incentivo e auxílio nas análises laboratoriais.

À Prof ${ }^{\underline{a}}$. Alda L. S. Lerayer pela amizade e pelo primordial apoio na participação em congressos na área de laticínios.

Ao Prof. Luiz Eduardo Gutierrez, pela amizade e pelos inúmeros auxílios e dicas em química e bioquímica.

Ao Prof. Flávio A. C. Tavares, pelo apoio decisivo ao encaminhar-me ao estudo dos queijos. 
À Marta R. Verruma-Bernardi, pela amizade e auxílio nas avaliações sensoriais.

À Sônia Piedade, pela colaboração nas análises estatísticas do experimento.

Às Bibliotecárias Beatriz Helena Giongo e Midian Gustinelli, pela amizade e auxílio nas correções e organização das referências bibliográficas.

Às estagiárias, Lilian P. Vendrametto, Luciana B. Jacob e Margarida Garcia de Figueiredo, pela amizade e colaboração nas análises físico-químicas.

A todos os meus amigos da pós-graduação, pelos momentos de alegria e de dificuldades compartilhados, eın particular Carlos E. Garcia, Cleomar M. de Carvalho, Cristiane Zovico, Fabiana M. de Siqueira, Ingrid Garboggini, Rudimar Cherubim, Tania R. F. Nardin, Viviane S. Monteiro.

Aos meus familiares e amigos, pela compreensão e apoio constantes, em especial, Nilza, Neide, Paulo e Cristina, Leopoldo e Liliane, Ronald, Ronan, Ana Maria, Daniela, Érika, Fernanda, Gisele, Luciane, Raquel.

À Agropecuária Santa Cruz, pelo fornecimento do leite in natura pasteurizado.

À Christian Hansen Ind. e Com. Ltda. (Valinhos, SP) pelo fornecimento das culturas láticas e do coalho.

À importadora New Zealand Milk Products, pelo fornecimento do leite em pó. 


\section{SUMÁRIO}

Página

LISTA DE FIGURAS..................................................................................... xi

LISTA DE TABELAS.............................................................................. xii

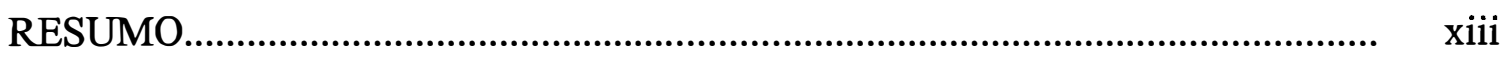

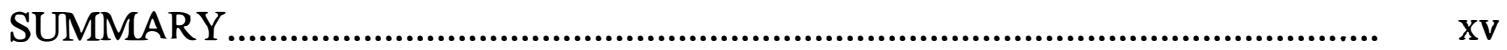

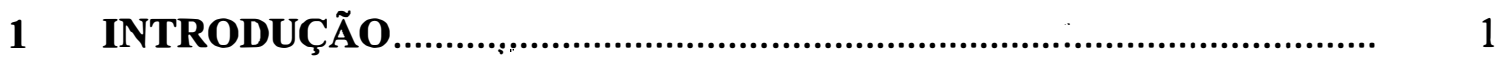

2 REVISÃO DE LITERATURA........................................................... 3

2.1 Sazonalidade da produçăo de leite no Brasil............................................... 3

2.2 A produção e o consumo de queijos no Brasil.......................................... 5

2.2.1 Fabricação do queijo Minas Frescal............................................................. 6

2.2.2 Características do queijo Minas Frescal.................................................. 7

2.3 O rendimento da fabricação de queijo........................................................... 8

2.3.1 Fatores que afetam o rendimento dos queijos......................................... 9

2.3.1.1 Composição do leite................................................................................. 10

2.3.1.2 Desnaturação protéica............................................................................ 11

2.3.1.3 Tipos de coalho................................................................................. 13

2.3.1.4 Composição do queijo........................................................................... 15

2.3.1.5 Perdas durante o corte da coalhada......................................................... 16

2.3.1.6 Ponto de massa ....................................................................................... 16

2.3.2 Formas de expressão do rendimento...................................................... 17

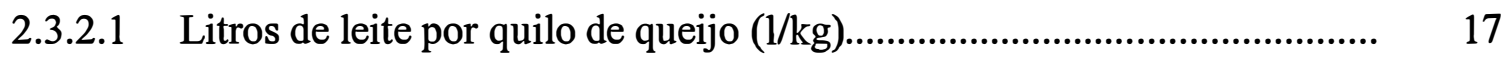

2.3.2.2 Cifras de transição..................................................................................... 18

2.3.2.3 Gramas de sólidos por quilo de leite........................................................ 19

2.4 Proteólise e durabilidade de queijos............................................................ 19

2.4.1 Definição de proteólise........................................................................... 20

2.4.2 Efeitos do teor de sal e atividade de água................................................... 21

2.4.3 Índices para avaliar a maturação de queijos............................................. 22 
2.5 O uso de leite em pó na fabricação de queijos............................................ 24

2.5.1 Histórico...................................................................................... 24

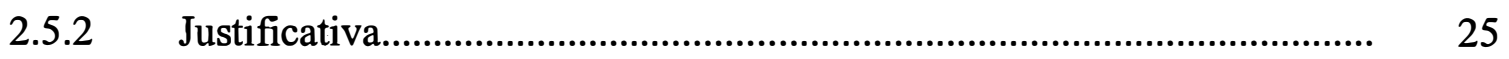

2.5.3 Qualidade do leite em pó para a fabricação de queijo............................... 26

2.5.4 Efeitos da utilização de leite em pó para a fabricação de queijos............. 28

2.5.4.1 Coagulabilidade................................................................................. 29

2.5.4.2 Sinerese e problemas de dessoragem..................................................... 30

2.5.4.3 Rendimento ............................................................................... 31

2.5.4.4 Mudanças na maturação e desenvolvimento de sabor e aroma................. 32

2.5.5 Tipos de queijos específicos fabricados a partir de leite reconstituído.... 34

2.5.5.1 Queijos brancos sem maturação............................................................ 35

2.5.5.2 Queijos de massa semi-cozida ........................................................... 36

2.5.5.3 Mussarela...................................................................................... 36

2.5.5.4 Queijo Azul.............................................................................. 37

3 MATERIAL E MÉTODOS............................................................ 38

3.1 Matéria-prima......................................................................... 38

3.1.1 Leite in natura .............................................................................. 38

3.1.2 Leite reconstituído .................................................................... 39

3.2 Coadjuvantes de processamento.......................................................... 39

3.2.1 Cloreto de cálcio.............................................................................. 39

3.2.2 Cloreto de sódio............................................................................ 39

3.2.3 Cultura lática..................................................................................... 39

3.2.4 Agente coagulante..................................................................... 39

3.3 Técnica de reconstituição do leite em pó e mistura ao leite in natura..... 40

3.4 Técnica de fabricação do queijo Minas Frescal....................................... 40

3.5 Análises físico-químicas do leite........................................................ 42

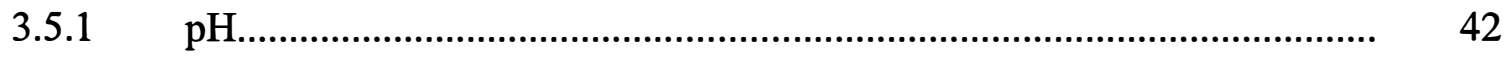

3.5.2 Acidez titulável............................................................................ 42

3.5.3 Densidade..................................................................................... 42 
3.5.4 Extrato seco total (EST) ................................................................ 42

3.5.5 Gordura......................................................................................

3.5.6 Proteína................................................................................. 43

3.5.7 Desnaturação das proteínas do soro do leite............................................. 43

3.6 Análises físico-químicas do soro............................................................. 43

3.7 Cálculos das porcentagens de transição de gordura e de sólidos totais do leite para o queijo.........................................................................

3.8 Cálculos de rendimento de fabricação.................................................... 45

3.9 Análises físico-químicas do queijo........................................................ 46

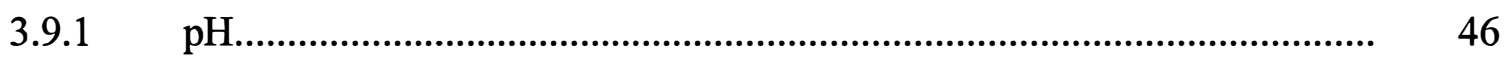

3.9.2 Acidez titulável......................................................................... 46

3.9.3 Umidade ....................................................................................... 47

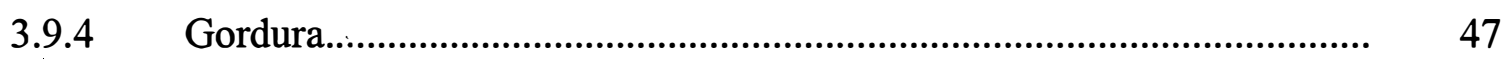

3.9.5 Gordura no extrato seco (GES)........................................................ 47

3.9.6 Cloreto de sódio................................................................................. 47

3.9.7 Sal na umidade do queijo.................................................................... 48

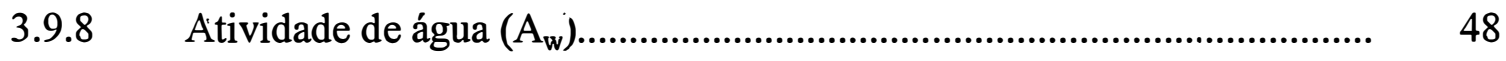

3.9.9 Nitrogênio total e proteína total............................................................. 48

3.9.10 Fracionamento do nitrogênio total............................................................ 49

3.9.10.1 Nitrogênio solúvel a pH 4,6................................................................. 49

3.9.10.2 Nitrogênio não protéico solúvel em TCA 12\%........................................ 49

3.9.11 Cálculo dos índices de extensão e profundidade da proteólise................. 49

3.9.12 Índice de tirosina..................................................................... 50

3.9.13 Análise sensorial.............................................................................. 50

$3.10 \quad$ Análise estatística.......................................................................... 51

4 RESULTADOS E DISCUSSÃO ......................................................

4.1 Composição físico-química do leite......................................................... 53

4.2 Desnaturação protéica do leite............................................................... 54

4.3 Processamento do queijo....................................................................... 55 
4.3.1 Ingredientes adicionados ao leite........................................................ 55

4.3.2 Coagulação e agitação........................................................................... 56

4.4 Composição do queijo.......................................................................... 57

4.5 Composição do soro.............................................................................. 59

4.6 Rendimento do queijo...................................................................... 60

4.7 Acompanhamento da vida de prateleira do queijo.................................... 62

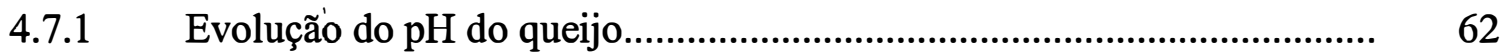

4.7.2 Evolução da acidez titulável do queijo........................................................ 63

4.7.3 Extensão da proteólise.......................................................................... 65

4.7.4 Profundidade da proteólise................................................................... 66

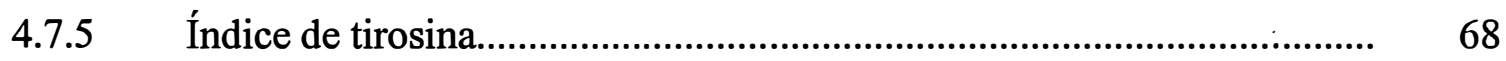

4.8 Avaliação sensorial...........................................................................

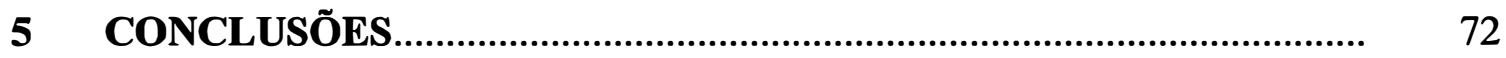

REFERÊNCIAS BIBLIOGRAFICAS.......................................................... 


\section{LISTA DE FIGURAS}

Página

1 Fluxograma de fabricação de queijo Minas Frescal com adição de leite

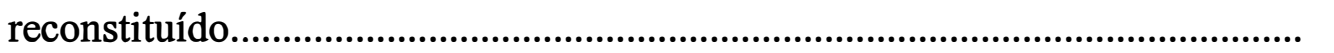

2 Ficha de avaliação sensorial apresentada aos degustadores................................. 52

3 Evolução do pH dos queijos, após 1, 7, 14 e 21 dias da fabricação, com 0, 10, 20 e $40 \%$ de leite reconstituído adicionado ao leite in natura...

4 Evolução da acidez titulável dos queijos, após 1, 7, 14 e 21 dias da fabricação, com $0,10,20$ e $40 \%$ de leite reconstituído adicionado ao leite in natura.

5 Evolução dos índices de extonsão da proteólise dos queijos, após 1, 7, 14 e 21 dias da fabricação, com $0,10,20$ e $40 \%$ de leite reconstituído adicionado ao leite in natura

6 Evolução dos índices de profundidade da proteólise dos queijos, após 1, 7, 14 e 21 dias da fabricação, com 0, 10, 20 e $40 \%$ de leite reconstituído adicionado ao leite in natura

7 Evolução dos índices tirosina dos queijos, após 1, 7, 14 e 21 dias da fabricação, com 0, 10, 20 e 40\% de leite reconstituído adicionado ao leite in natura

8 Freqüência de resposta do teste de aceitação (escala hedônica) de queijos elaborados com adição de 0, 10, 20 e 40\% de leite reconstituído adicionado ao leite in natura 


\section{LISTA DE TABELAS}

Página

1 Resultados médios da composição físico-química dos leites utilizados para a fabricação dos queijos

2 Resultados médios da porcentagem de desnaturação das proteínas do soro, dos leites empregados para a elaboração dos queijos

3 Tempos de floculação, coagulação e agitação observados durante as fabricações dos queijos

4 Composição físico-química média dos queijos um dia após a fabricação

5 Resultados médios da composição físico-química dos soros das fabricações dos queijos dos diferentes tratamentos

6 Rendimento médio das fabricações dos queijos

7 Evolução do $\mathrm{pH}$ dos queijos durante o ammazenamento

8 Evolução da acidez titulável dos queijos, expressa em porcentagem de ácido lático, durante o armazenamento

9 Índices de extensão da proteólise dos queijos durante o armazenamento.

10 Índices de profundidade da proteólise dos queijos durante o armazenamento.

11 Teores médios de tirosina $\mathrm{em}(\mathrm{mg} / 100 \mathrm{~g})$ dos queijos durante $\mathrm{o}$ amazenamento

12 Médias de notas dadas aos queijos na análise sensorial dois dias após a fabricação dos queijos, através de escala hedônica não estruturada 


\title{
ADIÇÃo DE LEITE RECONSTITUÍDO NA FABRICAÇÃO DE QUEIJO MINAS FRESCAL
}

\author{
Autora: LUCIANA VIRIATO SABOYA \\ Orientador: ANTONIO JOAQUIM DE OLIVEIRA
}

\section{RESUMO}

O queijo típico brasileiro, Minas Frescal, é o terceiro mais produzido no país e é consumido sem maturação. Entretanto, em certas épocas do ano, ocorre oscilações na produção de leite, devido ao próprio sistema de produção do país, diminuindo sua oferta no mercado. Assim, para suprir a demanda por queijos moles como o Minas Frescal, a utilização de leite reconstituído para fabricar queijos é uma das melhores formas de resolver esse problema, sem a necessidade de técnicas especiais de processamento e sem implicações em sua qualidade.

O fator mais importante quando se produz queijos utilizando leite reconstituído, é a necessidade de se empregar leite em pó do tipo "low-heat" ou "medium-heat" (baixo ou médio aquecimento térmico). Isso porque, esses tipos de pós, contêm menos proteínas do soro desnaturadas que pós submetidos a tratamentos térmicos severos. Assim, é essencial utilizar leite reconstituído com boa coagulabilidade e modificar levemente a tecnologia de fabricação, quando preciso.

Estudou-se a fabricação do queijo Minas Frescal utilizando-se leite in natura adicionado de 10, 20 e 40\% de leite reconstituído a partir de leite em pó integral "medium heat". Acompanhou-se as modificações no queijo durante a estocagem através de índices de proteólise e da determinação do $\mathrm{pH}$ e da acidez titulável dos queijos após 1, 7, 14 e 21 dias da fabricação. Determinou-se a transição dos componentes do leite para o queijo, como forma de estimař o rendimento da fabricação dos queijos. Os 
resultados demonstraram que não houve diferenças marcantes nos parâmetros estudados. Observou-se que o teor de umidade dos queijos fabricados com adição de leite reconstituído foi maior do que os queijos tradicionais $(p<0,01)$. Verificou-se que até 7 dias os produtos mantêm características que os identificam como aptos para o consumo, após o qual algumas mudanças foram detectadas, como produção elevada de acidez $\mathrm{e}$ degradação protéica intensa. A adição de leite reconstituído não afetou as perdas de gordura e nem de proteínas no soro. $\mathrm{O}$ rendimento expresso em gramas de sólidos totais por litro de leite empregado (g ST/L) foi mais elevado no queijo produzido com $40 \%$ de leite reconstituído adicionado ao leite in natura, embora não tenha sido significativamente diferente. Entretanto, a transferência de sólidos totais do leite para o queijo, foi significativamente superior $(\mathrm{p}<0,01)$ nesse mesmo tratamento. Concluiu-se que é possível produzir queijos de boa qualidade usando até $40 \%$ de leite reconstituído adicionado ao leite in natura. 


\title{
RECONSTITUTED MILK MIXTURES IN PASTEURIZED FRESH MILK FOR "MINAS FRESCAL" CHEESEMAKING
}

\author{
Author: LUCIANA VIRIATO SABOYA \\ Adviser: ANTONIO JOAQUIM DE OLIVEIRA
}

\section{SUMMARY}

The typical Brazilian cheese, "Minas Frescal", is the third most manufactured cheese in Brazil and is consumed in the fresh form. However, in certain periods of the year, occcurs a fluctuating supplies of fresh milk due to the milk production system in this country. Thus, to supply the demand for soft cheeses like "Minas Frescal", the processing of powdered milk into cheese after reconstitution is one of the best solutions to this problem, without special manufacturing techniques, with no changes in its quality.

The most important factor when making cheese from reconstituted milk is the necessity of milk powder of the low or medium-heat type. The reason for this is that powder of this type contains more undenatured whey protein than more severely heattreated powders. Thus, it is essential to use prepared milks with good rennetability and slightly modifies the cheese manufacture steps, whenever necessary.

"Minas Frescal" cheesemaking using mixes of fresh milk with different percentages $(0,10,20$ and $40 \%)$ of reconstituted medium heat dried whole milk was studied. Protein breakdown as well $\mathrm{pH}$, titratable acidity changes were monitored during cheese storage for 1, 7, 14 and 21 days. The transfer of milk components to cheese curd was carefully determined as a tool to estimate cheese maufacturing yield. Moisture contents of cheeses made from reconstituted milk were significantly higher than those of traditional $(\mathrm{p}<0.01)$ Minas Frescal cheese. It was observed that cheese kept its normal 
sensory atributes for up 7 days, after what some noticiable changes were detected, like excessive acidity production and protein breakdown. Addition of reconstituted milk did not affect fat and protein losses in the whey. Yield expressed as total grams of total solid matter per liter of milk (g TS/L), was higher in the "Minas Frescal" cheese added of $40 \%$ of reconstituted milk mixed to fresh milk, but it was not significant. However, the transfer of total solids milk to cheese curd was significantly higher $(p<0.01)$ in this same treatment. It was concluded that it is possible to produce a good quality "Minas Frescal" cheese using up to $40 \%$ of reconstituted milk mixed to fresh milk. 


\section{INTRODUÇÃO}

Dentre os queijos de maior importância no Brasil, está o queijo Minas Frescal, contando com $13 \%$ do consumo total de queijos, segundo a Associação Brasileira das Indústrias de Queijos - ABIQ. Isso se deve à sua tecnologia de fabricação ser bastante simples e difundida em todo o território nacional, além de ser um queijo muito apreciado.

É um queijo típico brasileiro, visto que foi desenvolvido nesse país, inicialmente em pequenas propriedades produtoras de leite, em Minas Gerais, de forma caseira, passando a fazer parte dos hábitos alimentares da região. Posteriormente, passou a ser apreciado em todo país, e sua tecnologia passou a nível industrial, exigindo uma padronização.

A produção de leite no Brasil é de caráter extensivo, sendo assim, registram-se, durante o ano, variações regulares, mas bastante importantes, da quantidade coletada pelas usinas. Ou seja, há um excedente de produção de leite durante o período de safra, quando se faz necessário desidratá-lo, visando sua melhor conservação e facilitar seu transporte para regiões de pouca produção de leite.

A demanda por queijo Minas Frescal, como para a maioria dos produtos lácteos, ocorre com mais intensidade no inverno, ou seja, na entressafra, quando justamente o leite in natura está em escassez. Por ser um queijo consumido logo após sua fabricação e de curta durabilidade, fica excluída a possibilidade de produzi-lo em períodos de elevada produção de leite, para ser estocado e consumido a posteriori.

O Minas Frescal, por ser um queijo mole, sem necessidade de maturação, permite ser fabricado utilizando-se leite reconstituído. Essa modificação em sua 
tecnologia, justifica-se em períodos ou locais onde a matéria-prima de fabricação, o leite fresco é escasso.

Assim, fabricando-se queijo Minas Frescal utilizando-se leite reconstituído como um meio alternativo de suprir a demanda do mercado, pode-se ter queijo o ano todo isento de oscilações de preço, sem que haja prejuízos em sua qualidade ou durabilidade.

Na manufatura do leite desidratado, ocorre desnaturação parcial das proteínas do leite e, quando este é utilizado no processo de fabricação do queijo, podem ocorrer modificações, principalmente quanto à coagulabilidade e sinerese. Com isso, é necessário ajustar alguns pontos na tecnologia de fabricação para obter-se queijos com as mesmas características e composição físico-química.

Assim sendo, os objetivos desse trabalho foram avaliar o uso de diferentes níveis de leite reconstituído na fabricação de queijo Minas Frescal e, para tanto, estudar os efeitos da utilização de leite reconstituído na composição do queijo e no rendimento da fabricação; estimar a durabilidade do queijo Minas Frescal quando adicionado de leite reconstituído e avaliar a aceitação dos queijos fabricados com a adição de leite reconstituído sob o ponto de vista sensorial. 


\section{REVISÃO DE LITERATURA}

\subsection{Sazonalidade da produção de leite no Brasil}

A sazonalidade da produção agrícola é um problema universal. As estações dão ritmo ao ciclo produtivo vegetal e animal, de acordo com a influência climática à qual está exposta a produção agropecuária. Assim, os produtos atingem o pico de produção em tempos favoráveis e desaparecem quando o tempo é adverso, ou seja, safra e entressafra, respectivamente (Primo, 1996a). Exemplo típico é o que ocorre com a produção de leite no Brasil. Na safra, a produção de leite atinge, muitas vezes, patamares tão elevados que as usinas não são capazes de beneficiá-lo, ou então, é comprado por preços irrisórios dos fornecedores. No entanto, no período seco, o que acontece é exatamente contrário; os produtores de leite não conseguem suprir a demanda dos laticínios, época em que os produtos lácteos são mais requeridos pelo consumidor. Geus (1996), vê o aspecto da sazonalidade como um grave problema no Brasil, com o safrista produzindo mais leite na entressafra, com um rebanho não especializado, obtendo mais leite na safra e quase nada na entressafra .

Ante essa situação, países como EUA, União Européia, Nova Zelândia, Austrália, Japão e Canadá trataram de implementar políticas econômicas visando superar as limitações impostas pela natureza. Dessa forma, em algumas décadas, esses países conseguiram diminuir as diferenças de produção verificadas na safra e entressafra, transformando os excedentes da primeira em estoques estratégicos a serem utilizados em períodos de recesso de produção, em função de suas políticas globais (Primo, 1996a).

Quando se analisa a produção de leite por vaca e o consumo de leite e derivados per capita de um país, percebe-se que a produtividade do rebanho é um 
indicador de desenvolvimento econômico. Índices baixos e marcante sazonalidade da produção são evidências de atraso da atividade, como ocorre no Brasil que possui uma produção média inferior de $2.000 \mathrm{Kg}$ de leite/vaca/ano. Podem considerar-se subdesenvolvidos países cuja produção de leite estiver em torno de $3.000 \mathrm{Kg}$ de leite/vaca/ano (Primo, 1996a).

A fragilidade da produção de leite brasileira na entressafra torna-se traumática e evidencia os desequilíbrios do setor primário. As razões da insuficiência da oferta vão além da questão da sazonalidade da produção. Explica-se principalmente pelo atraso tecnológico em que se encontra a pecuária leiteira nacional, resultado da falta de intervenção governamental sobre o setor leiteiro e de laticínios (Primo, 1996a).

As indústrias completam com matéria-prima importada a queda de produção da entressafra, abastecendo o mercado ineterruptamente. Florescem empresas importadoras/empacotadoras, principalmente de leite em pó, que possuem grandes vantagens competitivas por absorverem apenas um elo da cadeia, onde os investimentos são menores, quase nenhum risco, ociosidade zero e nenhum compromisso com os produtores (Primo, 1996b).

A sazonalidade da produção leiteira no Brasil ocorre de março até agosto, com a produção aumentando a partir de setembro. Ou seja, nesse período a curva de produção atinge valores muito baixos, quando, então, há a necessidade de suprir o mercado importando produtos lácteos de outros países.

O leite em pó importado na entressafra, com os subsídios existentes no exterior, chega mais barato do que o mais barato dos leites aqui produzidos (Xavier, 1997). Dessa forma, utilizando-se leite em pó, importado ou não, pode-se abastecer o mercado quando houver escassez de produção de leite in natura, quer seja para fabricação de queijos, como produtos lácteos em geral, ou ainda, na obtenção de leite fluido. 


\subsection{A produção e o consumo de queijos no Brasil}

A produção de queijos no Brasil em 1987, segundo Furtado (1990), foi de 240.798 toneladas sem incluir o requeijão. Essa produção corresponde a um consumo per capita de cerca de apenas $1,7 \mathrm{Kg}$ de queijo anualmente, média ainda inferior à de países industrializados. O queijo Minas ainda ocupa o terceiro lugar na produção nacional de queijos (27.628 toneladas, incluindo as variedades Frescal e Padronizado), mas a produção sofreu reversão de tendência a partir de 1980, quando então o Minas Padronizado era fabricado em quantidades duas vezes superior ao Minas Frescal. Em 1987, a produção do Minas Frescal foi de 26.609 toneladas, enquanto que a do Minas Padronizado foi de apenas 1.010 toneladas. Esta nova tendência tem sido explicada pela preferência das empresas em produzir o Minas Frescal, um queijo de maior rendimento, que não requer maiores investimentos em estocagem e conservação, necessitando de menor capital de giro; por outro lado, isso permite que o queijo seja colocado no mercado a um preço mais vantajoso para o consumidor, o que explica a alta demanda do produto nos últimos tempos.

Em 1992, a produção total de queijos, segundo a ABIQ (Associação Brasileira das Indústrias de Queijo), foi da ordem de 189.149 toneladas, sendo que 16.155 toneladas são atribuídas ao queijo Minas Frescal.

A previsão de produção de queijos feita pela ABIQ para 1997 é de cerca de 410 mil toneladas. Em 1996, este número foi de 385 mil toneladas e em 1995, de 360 mil toneladas, refletindo numa menor importação desse produto (Galan, 1997).

Essa mesma associação, a ABIQ, em pesquisa do mercado de queijos, realizada na cidade de São Paulo em julho de 1996, com consumidores na faixa etária entre 30 e 60 anos, das classes A, B, C e D, constatou que existe uma aceitação generalizada, em todas as classes sociais, dos queijos Minas Frescal, Prato, Mussarela, Provolone, Parmesão, Requeijão e Ricota. Já os queijos ditos especiais, limitam-se apenas às classes $\mathrm{A}$ e $\mathrm{B}$ e alguns na classe $\mathrm{C}$, destacando-se o Gorgonzola. Quanto à maneira de consumir cada tipo de queijo, constatou-se o seguinte: a Mussarela tem seu 
uso na culinária apontado por $40 \%$ das entrevistadas, em média, diminuindo para $30 \%$, na classe D. O Minas Frescal é mais consumido em lanches e café da manhã, 84\% em média; o queijo Prato, no lanche, 37\%; Requeijão, 13\%, no café da manhã, e, $14 \%$ no lanche; o Parmesão, 19\%, na culinária (Teixeira Jr., 1996).

\subsubsection{Fabricação do queijo Minas Frescal}

O queijo Minas Frescal é um dos produtos mais largamente fabricados na indústria de laticínios do país. Tem grande aceitação no mercado e, além disso, apresenta diversas vantagens do ponto de vista tecnológico: é um produto de fácil elaboração, apresenta elevado rendimento na fabricação e, sobretudo, não tem maturação, o que facilita grandemente seu escoamento e distribuição no mercado (Wolfschoon-Pombo et al., 1978).

Possui uma tecnologia de fabricação bastante simples e por isso muito difundida, permitindo inclusive sua aplicação caseira e em fazendas, onde na verdade teve sua origem, notoriamente no Estado de Minas Gerais. Com a evolução das técnicas industriais, a tecnologia de fabricação sofreu modificações, visando ora a melhoria da qualidade do produto, ora um aumento no rendimento da fabricação, ou ainda, maior padronização do produto final. Nesta evolução constante, modificações diversas surgiram, entre elas a fabricação com leite pasteurizado, o uso de cloreto de cálcio, e o emprego de fermento lático, dentre outras, como a substituição do fermento lático tradicional (Lactococcus lactis subsp. lactis e L. lactis subsp. cremoris) pelo uso de ácido lático industrial (Furtado et al., 1980).

$\mathrm{Na}$ indústria, predomina o emprego da tecnologia tradicional, com uso de leite pasteurizado (obedecendo à prescrição legal) e adição de culturas láticas mesófilas. No entanto, o emprego do fermento lático para um queijo de consumo imediato como o Minas Frescal parece incoerente. Contudo, a ausência de culturas láticas pode levar a um produto de sabor bem mais fraco e maior tendência a estufamento, em caso de uma eventual contaminação com bactérias produtoras de gás, como aquelas do grupo coliforme (Furtado et al., 1980). 


\subsubsection{Características do queijo Minas Frescal}

Classificado como mole e gordo, o queijo Minas Frescal, segundo Saito \& Schiftan (1978), por definição das Normas Técnicas Especiais Relativas a Alimentos e Bebidas (Decreto Estadual número 52.504 de 28 de julho de 1970), é o produto obtido de leite pasteurizado integral ou parcialmente desnatado, comprimido, levemente prensado ou não, exposto à secagem por 2 a 3 dias e consumido imediatamente. Deve apresentar, de preferência, formato cilíndrico baixo, de 4 a $7 \mathrm{~cm}$ de altura, tamanho médio, com peso variando de 0,5 a $1,5 \mathrm{Kg}$ aproximadamente, com bordos retos e faces planas, formando ângulos vivos. A crosta deverá ser mal formada, a consistência macia $\mathrm{e}$ de untura manteigosa, a textura deverá apresentar olhaduras mecânicas pequenas e pode apresentar ou não olhaduras em forma de cabeça de alfinete. Suas características sensoriais são aspecto de massa mole, coloração branco-creme homogênea, cheiro e sabor próprios, suave e levemente ácido. Deve apresentar um máximo de umidade $57 \% \mathrm{e}$ um mínimo de $40 \%$ de gordura no extrato seco (GES).

A composição recomendada pela ABIQ para o rótulo do queijo Minas Frescal é de 40\% (mínimo) de GES, 16 g de lipídios/100g; $2 \mathrm{~g}$ de glicídios/100g; $18 \mathrm{~g}$ de proteínas/100g; $225 \mathrm{Kcal} / 100 \mathrm{~g}$ (Rótulos... 1996).

O queijo Minas Frescal, segundo Furtado \& Lourenço-Neto (1994), é um dos queijos mais populares do Brasil. Devido ao bom rendimento $(6,0-6,51 / \mathrm{Kg}$, em média), é comercializado a preços mais acessíveis a uma maior parte da população. Por possuir alto teor de umidade, é um queijo bastante perecível, com uma durabilidade média de 10 dias, dependendo do processo de fabricação. Devido à adoção de diferentes métodos de fabricação, como por exemplo, com adição de ácido lático ou emprego tradicional de fermento, assim como variações na temperatura de coagulação ou até mesmo emprego de prensagem, entre outros, tornou-se um queijo bastante irregular em termos de padrões de consistência, textura, sabor, durabilidade e rendimento, chegando inclusive a ser fabricado através do processo de ultrafiltração. Geralmente, apresenta coloração interna esbranquiçada, consistência mole, textura fechada, com algumas 
olhaduras irregulares, e, sabor variando de levemente ácido a suave. $\mathrm{O}$ peso varia de 0,5 a 3,0 Kg, sendo comercializado geralmente em formas de menor peso. A composição média esperada do queijo Minas Frescal, é de 55 - 58\% de umidade, 17 - $19 \%$ de gordura, $1,4-1,6 \%$ de sal e $\mathrm{pH}$ de 5,0 - 5,3 .

O Minas Frescal é um queijo que apresenta vários pontos críticos durante a fabricação que podem conduzir a alterações no produto final. Pode apresentar-se tanto com acidez excessiva como insuficiente, com reflexos no desenvolvimento de contaminações. Essas alterações influenciam a umidade final, o sabor do queijo, o rendimento e a durabilidade, afetando diretamente as características sensoriais e conseqüentemente a aceitabilidade pelo consumidor e comercialização (Furtado \& Lourenço-Neto, 1994).

Por apresentar elevado teor de umidade e elevada quantidade de lactose, açúcar facilmente decomposto nas diversas fermentações susceptíveis de ocorrer em um queijo, o Minas Frescal é um queijo facilmente perecível. A acidificação, fenômeno causado pela atuação das bactérias do fermento lático, é apontada como a causa mais freqüente da deterioração do Minas Frescal no mercado (Wolfschoon-Pombo et al., 1978).

\subsection{0 rendimento da fabricação de queijo}

O rendimento é um aspecto importante na fabricação de queijos, pois assim, pode-se conhecer a lucratividade numa indústria queijeira. Segundo Furtado \& Wolfschoon-Pombo (1979a), o conhecimento da relação entre a composição do leite e o rendimento do queijo é de interesse prático e econômico para os fabricantes de queijos.

Vandeweghe \& Maubois (1986) definem o rendimento de queijo, ou rendimento da conversão de leite em queijo, como sendo uma expressão matemática para a quantidade de queijo obtida de uma dada quantidade de leite (freqüentemente 100 1 ou $100 \mathrm{~kg}$ ). Entretanto, outras formas de expressão podem ser usadas para exprimir essa mesma idéia: o número de litros usados para fazer um queijo, ou um quilo de 
queijo; a proporção de um dado constituinte ou um grupo de constituintes do leite (sólidos não gordurosos, proteínas, caseínas) que permanecem no leite.

Cada componente individual do leite tem um valor peculiar em relação às propriedades do queijo e ao processo de fabricação; conseqüentemente, o conhecimento desses valores individuais é importante para a elaboração do queijo. Os processos microbiológicos e enzimáticos da maturação do queijo dependem do conteúdo em água livre; regulando-se o conteúdo em água, obtém-se no queijo a textura e consistência desejadas; o teor de proteínas é importante no processo de coagulação, na retenção da água, no rendimento e na maturação; a gordura contribui para o aroma do queijo e o rendimento, melhora a consistência e, durante a maturação, confere ao queijo características peculiares; a lactose, devido às transformações que sofre pela ação de enzimas bacterianas durante a fabricação, confere ao queijo parte do sabor e odor característicos; os sais são. responsáveis pela formação do complexo da micela das caseínas e exercem influência sobre a qualidade do queijo produzido (Furtado \& Wolfschoon-Pombo 1979a).

\subsubsection{Fatores que afetam o rendimento dos queijos}

Muitos são os fatores que afetam o rendimento de um queijo. Assim, é preciso conhecer os principais fatores que podem estar interferindo no rendimento do queijo, para que não sejam atribuídas certas modificações do mesmo à somente falhas no processo de elaboração.

Os principais fatores que podem interferir no rendimento dos queijos são: composição do leite (principalmente gordura e proteína), porcentagem de transição dos constituintes do leite para o queijo e a porcentagem de umidade retida (Banks et al., 1981). Também são decisivos para o rendimento de queijos a qualidade do leite, aditivos (coalho e fermento lático) e a tecnologia de fabricação empregada. Os tratamentos térmico e mecânico aplicados ao leite e à coalhada, durante o processamento, podem influenciar o rendimento da fabricação de queijo. 
A seguir serão enfocados alguns aspectos de relevância que podem afetar o rendimento da fabricação de um queijo.

\subsubsection{Composição do leite}

A composição do leite é fundamental e não somente no que se refere ao teor de gordura do leite, como se pensa com freqüência. É evidente que quanto mais gordo for o leite, maior é a probabilidade de se obter um melhor rendimento na fabricação. Afinal, os glóbulos de gordura, em sua grande maioria, são aprisionados pela coalhada, no momento em que o leite coagula. No entanto, a coalhada é formada por uma rede ou um entrelaçado protéico, constituído basicamente de caseína e cálcio, o que implica dizer que se o teor de caseína (proteína) do leite for baixo, mesmo que o teor de gordura seja alto, o rendimento será menor que o esperado. Isso acontecerá porque não somente haveria menor quantidade de caseína a se incorporar no queijo, como também ocorreria uma maior perda de gordura no soro (Furtado \& Lourenço-Neto, 1991b).

Gallina \& Brandão (1996) afirmam que um aumento de gordura no leite, mantendo-se o teor de caseína constante, incrementa o rendimento na produção de queijos, porque maior quantidade de gordura ficará retida na massa. Isso ocorre porque os queijos terão menor porcentagem de proteínas e conseqüentemente, menos água absorvida. As proporções umidade:sólidos não gordurosos e a umidade:caseína também aumentam, provavelmente em razão da interferência mecânica da gordura no processo de sinerese. Por isso, deve-se utilizar uma relação padronizada de gordura:caseína para que o queijo produzido também tenha composição padronizada.

Quanto à composição biológica do leite, que também afeta o rendimento dos queijos, merecem a atenção a contagem de células somáticas, relacionadas à mastite, bem como, a qualidade microbiológica associada à higiene do leite. $\mathrm{O}$ uso de leite mastítico para a produção de queijos acarreta redução no seu rendimento, devido a um aumento de proteólise ocasionado pelas células somáticas presentes nesse tipo de leite. Queijos produzidos com leite mastítico apresentam longo tempo de coagulação, gel com 
baixo grau de firmeza, e alto teor de umidade. A presença de alta concentração de microrganismos no leite, principalmente de bactérias psicrotróficas, interfere negativamente no rendimento, na firmeza do coágulo e tende a aumentar a umidade dos queijos (Gallina \& Brandão, 1996).

\subsubsection{Desnaturação protéica}

Sabe-se que o aquecimento do leite resulta na desnaturação de certas proteínas termolábeis. Essa desnaturação manifesta-se na precipitação de proteínas, permitindo sua recuperação no coágulo drenado e no aumento do rendimento de sólidos (Hardy,1986).

As soroproteínas diferem-se das caseínas quanto à sua estrutura e propriedades. Assim, essas proteínas, ao contrário das caseínas, não estão associadas em micelas, mas encontram-se molecularmente dissolvidas e susceptíveis à desnaturação térmica. Essa termolabilidade das soroproteínas é uma conseqüência da estabilidade marginal da sua compacta estrutura tridimencional (De Wit, 1981).

Segundo Parry Jr. (1974), as soroproteínas estão sujeitas à variações mais acentuadas que as caseínas e são particularmente afetadas pelo período de lactação. Quando desnaturadas, as soroproteínas perdem sua solubilidade na região isoelétrica, ou em soluções salinas e coprecipitam com as caseínas.

A temperatura a que o leite é submetido durante o processamento conduz a mudanças físico-químicas nas diferentes frações protéicas e, correspondentemente, na distribuição do nitrogênio das mesmas (Wolfschoon-Pombo et al., 1982). Vários estudos demonstram que, dentre as proteínas do leite, as soroproteínas são as mais termolábeis, sendo a alfa-lactoalbumina a mais resistente ao tratamento térmico. A ordem de instabilidade térmica é: Imunoglobulinas $<$ Albumina do soro bovino $<\beta$-lactoglobulina $<\alpha$-lactoalbumina (Hardy,1986; Pany Jr., 1974; Covarrubias et al., 1988).

As proteínas do soro e as caseínas são afetadas pelo aquecimento de 
várias formas. $\mathrm{O}$ aquecimento promove uma forma de desnaturação, principalmente das soroproteínas, e fornece a energia que torna possível a ocorrência de reações químicas. De forma geral, o resultado do aquecimento do leite a temperaturas superiores a $100^{\circ} \mathrm{C}$, causa a eventual precipitação de caseína e de micelas de caseínas, embora a forma de ocorrência de tais reações não sejam totalmente determinadas. Além dos efeitos diretos sobre as proteínas, o aquecimento também aumenta a quantidade de ligações de $\mathrm{Ca}^{2+}$ às caseínas e pode também iniciar a precipitação ou deposição de fosfato de cálcio sólido, além daqueles já presentes na micela (Dalgleish, 1982).

Segundo Parry Jr. (1974), a desnaturação das proteínas do soro modifica a coagulação do leite e as propriedades reológicas da coalhada formada por acidificação ou por enzimas. Quando o leite é aquecido à temperaturas que desnaturam as proteínas do soro, haverá como conseqüências sabor e aroma de cozido e maior resistência à coagulação pela renina. Tais mudanças são significativas na prática de produção de queijos, leite em pó e produtos lácteos concentrados.

O efeito do calor sobre as proteínas deve ser considerado como um processo de dois estágios: (1) alteração da estrutura secundária e terciária, causando a desnaturação e (2) agregação de proteínas, o que pode levar à coagulação (Parry Jr., 1974).

$\grave{A}$ temperaturas na faixa de $80^{\circ} \mathrm{C}$, a $\beta$-lactoglobulina é desnaturada. Essa desnaturação representa uma alteração da estrutura tridimensional da proteína, com um intercâmbio de pontes de dissulfeto. Assim, ao invés da estrutura única, uma multiplicidade de estruturas são formadas (Dalgleisn, 1982).

Dessa forma, é de se esperar um comportamento ligeiramente diferente da soroproteína de leite fervido, se comparado ao pasteurizado, por exemplo, em relação à capacidade de absorver água, de geleificar, emulsificar, à viscosidade, etc. (WolfschoonPombo et al., 1982).

Essas proteínas desnaturadas têm maior capacidade de ligar-se à água do que à paracaseína, particularmente em atividades de água mais elevadas. Assim, a uma 
atividade de água de 0,9 , a $\beta$ - lactoglobulina absorve $0,282 \mathrm{~g}$ de água por grama de proteína, enquanto que um grama de paracaseína absorve somente $0,240 \mathrm{~g}$. Em termos de água não congelável, pode ser notado que as proteínas do soro, as quais são desnaturadas pelo calor, contêm $0,47 \mathrm{~g}$ de água por grama de proteína, enquanto que a caseína contém 0,437 g. Portanto, se o leite a ser usado na fabricação de queijo for aquecido o suficiente para insolubilizar as proteínas do soro, haverá como resultado um aumento da quantidade de água ligada no queijo (Hardy,1986).

Dessa forma, a pasteurização do leite não somente destrói as bactérias patogênicas como também aumenta o rendimento dos queijos, devido à desnaturação parcial das proteínas do soro e de sua fixação na superficie dos glóbulos de gordura. Diversos fatores afetam o aumento do rendimento, incluindo o tempo e a temperatura do tratamento, o tipo do queijo, uso de ácidos e de cloreto de cálcio e idade do queijo na hora de avaliar o rendimento. $\mathrm{O}$ aumento do rendimento devido à pasteurização afeta $\mathrm{o}$ coágulo de duas maneiras: coagulando parte das proteínas do soro e aumentando o teor de umidade do queijo. Porém, as proteínas do soro insolubilizadas pelo calor enfraquecem a textura do coágulo, causando aumento de perdas de pequenos coágulos de caseína no soro. $\mathrm{O}$ incremento da quantidade de proteínas do soro na massa do queijo melhora o rendimento, mas também afeta a estrutura não só do queijo como do coágulo na hora do corte da massa. A pasteurização aumenta o rendimento do queijo quando comparado ao leite cru. Aproximadamente $5 \%$ do total das proteínas do soro estão associadas às micelas de caseína após a pasteurização (Gallina \& Brandão, 1996).

\subsubsection{Tipos de coalho}

O coalho, sendo um elemento essencial na fabricação da grande maioria dos queijos, possui ação fundamental para coagular o leite e maturar o queijo, compondo-se, basicamente, de duas enzimas: renina (quimosina) e pepsina (Furtado \& Lourenço-Neto, 1991a). 
A primeira função da renina é especificamente hidrolisar o componente de estabilização da micela de caseína, a א-caseína, com um mínimo de proteólise (que reduz o rendimento do queijo). A firmeza do gel e, conseqüentemente, o rendimento do queijo são influenciados pela ação da renina ou coalho (Fox, 1988).

A pepsina desenvolve sua função mais ativamente no período de cura, quando a enzima degrada a cadeia protéica e torna a massa do queijo mais fina e solúvel. Se houver um excesso de pepsina no coalho, há maior chance do queijo vir a produzir sabor amargo durante a maturação. Além disso, é importante ressaltar que a pepsina é praticamente inativada em $\mathrm{pH}$ superior a 6,7 o que, do ponto de vista prático, tem uma importância fundamental: ao se juntar um leite de ótima qualidade (acidez de 14 a $16^{\circ} \mathrm{D}$ ) com um coalho de qualidade duvidosa (excesso de pepsina), a coagulação pode ocorrer de forma inadequada, ocasionando perdas excessivas de gordura no soro, com queda no rendimento da fabricação final (Furtado \& Lourenço-Neto, 1991a).

Existe uma grande variedade de proteinases que tem sido usadas como coagulantes do leite, como as enzimas microbianas, as enzimas extraídas de plantas (ficina, bromelina, papaína) e as proteinases gástricas de vitelos, cabritos e cordeiros (Fox, 1988).

O coalho de vitelo (com aproximadamente $90-94 \%$ de quimosina), possui a atividade proteolítica e de coagulação do leite mais elevada das reninas comerciais já testadas. A atividade proteolítica das proteinases gástricas comerciais diminuem na seguinte ordem: pepsina de ave $>$ pepsina suína $>$ pepsina ovina $>$ pepsina bovina $>$ renina/quimosina de vitelo (Guinee \& Wilkinson, 1992).

O coalho tradicional é extraído do abomaso de bovinos jovens ou adultos; a idade do animal tem forte influência na composição do coalho, já que em bovinos adultos a enzima predominante é a pepsina. A mistura pepsina-renina pode variar bastante; assim, prefere-se coalhos com alto teor de renina, pois além desta ser menos proteolítica do que a pepsina, atua em uma faixa mais ampla de $\mathrm{pH}$. Com a biotecnologia, foi possível desenvolver um coalho contendo $100 \%$ de renina, através de 
processo fermentativo. A renina do coalho genético, é idêntica, química e funcionalmente, àquela extraída do estômago de ruminantes jovens. Outro coalho existente é o microbiano (fúngico) que é derivado de fungos e possui outras enzimas diferentes da renina, sendo por isso mais recomendado para queijos sem maturação (Furtado \& Lourenço-Neto, 1992).

Assim, segundo Gallina \& Brandão (1996) o coagulante usado na fabricação de queijo pode influenciar o rendimento, pois aqueles que possuem alta atividade proteolítica reduzem o teor de proteína na massa, além de aumentar o risco de proteólise descontrolada. Em geral, a renina (quimosina) é considerada o coagulante preferido para um ótimo rendimento do queijo.

\subsubsection{Composição do queijo}

Os componentes do leite são elementos determinantes para a composição e para o rendimento do queijo. A gordura, a caseína e outros sólidos do leite, umidade, além do teor de sal adicionado são os componentes chaves. Assim, a eficiência da recuperação de gordura, da proteína e outros sólidos do leite, além do controle da umidade e do teor de sal do queijo, terão influência direta no rendimento de queijos (Barbano, 1996).

Uma pequena variação no teor de umidade (água) de um queijo, pode representar uma quantia considerável do ponto de vista econômico. Por exemplo, a temperatura de cozimento exerce grande influência no rendimento do queijo Prato, pois afeta muito a umidade retida nos grãos. Assim, se a massa é aquecida a $40^{\circ} \mathrm{C}$ numa fabricação e $42^{\circ} \mathrm{C}$ em outra, esta última, mantidas as demais condições em igualdade, terá menor teor de umidade e menor rendimento (Furtado \& Lourenço-Neto, 1991b).

Aumentando-se a umidade e o teor de sal em um queijo, como por exemplo a Mussarela, aumenta-se o rendimento desse queijo. Com o aumento da umidade, haverá um duplo impacto sobre o rendimento do queijo, como pode ser demonstrado por uma fórmula de rendimento. Primeiramente, há um impacto direto pelo 
aumento de peso de água; em segundo, devido ao aumento na quantidade total de outros sólidos retidos na fase aquosa do queijo (Barbano, 1996).

\subsubsection{Perdas durante o corte da coalhada}

A maneira pela qual a coalhada é cortada tem uma influência muito grande no rendimento final da fabricação. A coalhada deve ser cortada quando apresentar um grau mínimo de firmeza, que varia de acordo com o queijo a ser fabricado. Em geral, quanto mais gordo for o leite, mais firme deve ser cortada a coalhada, para se evitar perdas excessivas de gordura no soro. Em situações normais, a perda no soro não deve exceder cerca de $15 \%$ do teor de gordura original do leite, ou seja, em leite com $3,6 \%$, admite-se um soro com até cerca de $0,54 \%$ (ao final da agitação). Alguns fatores, que podem provocar maior perda de gordura e proteínas no soro, devem ser observados, tais como: corte e agitação inicial rápidos demais; uso de coalho de má qualidade ou em dosagem inadequada; temperatura de coagulação baixa (menor que $32^{\circ} \mathrm{C}$ ); leite muito ácido; corte da coalhada antes do ponto; leite super aquecido na pasteurização; não utilização de cloreto de cálcio; leite com baixo teor de caseína ou de cálcio (Furtado \& Lourenço-Neto, 1991b).

\subsubsection{Ponto de massa}

Ao final do processo de elaboração do queijo, sob influência da acidificação, da agitação e do calor utilizado no cozimento, os grãos de massa tornam-se mais enxutos e com base na prática e experiência, é dado o ponto na massa que obviamente varia em função de diversos fatores como: tipo de queijo (mais firme ou macio); tipo de consumo (fatiamento ou para mesa); destino (estocagem longa ou maturação e venda); época do ano (inverno ou verão) (Furtado \& Lourenço-Neto, 1991b).

O ponto de massa, além de determinar uma série de fatores que afetam a qualidade do queijo, tem grande influência no rendimento, pois responde pela 
quantidade de água que ficará retida no queijo. Uma pequena variação no teor de umidade (água) de um queijo, pode representar uma quantia considerável do ponto de vista econômico (Furtado \& Lourenço-Neto, 1991b).

\subsubsection{Formas de expressão do rendimento}

Existem várias maneiras de se expressar o rendimento de um queijo. Muitas fórmulas foram desenvolvidas para predizer o rendimento de queijos. Segundo Emmons et al. (1990), as fórmulas utilizadas para o cálculo do rendimento, dividem-se em duas classes gerais, baseando-se na composição do queijo, ou então sendo derivadas da comparação do rendimento real e composição do leite utilizado, normalmente teores de caseína, gordura e sólidos solúveis.

\subsubsection{Litros de leite por quilo de queijo $(\mathrm{l} / \mathrm{kg})$}

A expressão do rendimento de queijo através da relação entre litros de leite empregados na fabricação por quilos de queijo obtido ao final do processo $(1 / \mathrm{kg})$, é ainda a forma mais utilizada pelos laticínios do país. No entanto, pode-se cometer erros na interpretação desses dados, visto que essa forma de expressão não leva em consideração o teor de umidade do queijo, que pode variar muito, dependendo da tecnologia adotada, entre outros fatores intrínsecos. Não se leva em conta o aproveitamento dos nutrientes do leite retidos no queijo que varia, em princípio, com a própria composição do leite utilizado. Assim, fica claro que essa forma de expressão de rendimento é válida somente em termos gerais de classificação de queijos; não o sendo quando se quer comparar resultados de vários processamentos.

Segundo Furtado \& Lourenço-Neto (1991b), os rendimentos médios considerados normais (em litros de leite por quilo de queijo, logo após a fabricação), de alguns tipos de queijos, variam para, Minas Frescal, de 5,7 a 6,5; Minas Curado, de 8,0 a 8,5; Prato, de 8,8 a 9,5; Mussarela, de 9,5 a 10,0; Parmezão, de 11,0 a 12,0. 


\subsubsection{Cifras de transição}

O rendimento das fabricações de queijos pode ser determinado com base nas cifras de transição dos principais constituintes do leite para o queijo.

A determinação das cifras de transição é feita utilizando-se cálculos matemáticos, baseados na composição físico-química do leite e soro da fabricação do queijo envolvido, bem como na composição físico-química do queijo obtido e o seu rendimento. As cifras de transição, além de oferecer uma idéia acerca da passagem dos componentes do leite ao queijo e de dar uma imagem das perdas valiosas que ocorrem no soro, nos permitem estabelecer, de forma empírica, equações para prever o rendimento na fabricação de determinado tipo de queijo (Furtado \& Wolfschoon-Pombo, 1979a).

Estudando o rendimento da fabricação dos queijos Prato e Minas, através da determinação das cifras de transição de elementos, Furtado \& Wolfschoon-Pombo, (1979a; 1979b), puderam, dessa forma, estabelecer uma composição físico-química média para os soros resultantes das fabricações dos queijos; também estabeleceram o teor médio de gordura que deve ficar no queijo, contribuindo, assim, à padronização desses queijos.

A recuperação da gordura no queijo, ou seja, o peso de gordura no queijo por $100 \mathrm{Kg}$ de gordura no leite, varia de 85 a 94\%, dependendo de diversos fatores, como a ruptura mecânica da membrana dos glóbulos de gordura, corte inapropriado da massa, formato do tanque de fabricação, estação do ano (Gallina \& Brandão, 1996).

Já a recuperação de caseína varia entre 93,5 a 96\%. Pelo menos $4 \%$ da caseína são inevitavelmente perdidos no soro na forma de glicomacropeptídeo e de proteose-peptona formada devido à ação da plasmina na beta-caseína. Além desses fatores, pequenas partes da coalhada (finos) são perdidas em conseqüência do corte e da agitação. A estação do ano também influencia na recuperação de caseína. É preciso ressaltar que a perda de caseína também causa a perda de água a ela associada (Gallina \& Brandão, 1996). 


\subsubsection{Gramas de sólidos por quilo de leite}

Uma outra maneira de se determinar o rendimento é através do cálculo da quantidade de sólidos retida no queijo em relação ao volume de leite trabalhado. Neste caso, pesa-se a produção de queijos obtida (antes da salga em salmoura) e o peso resultante é, então, multiplicado pela porcentagem de sólidos totais do queijo, obtendose, assim, o valor real dos sólidos que transitaram do leite para a massa no momento do corte da coalhada. Este valor é, então, dividido pelo volume de leite (em litros) trabalhado. Este método apresenta as vantagens de ser simples e de expressar o rendimento, eliminando possíveis desvios quando a umidade apresentada pelo queijo não é considerada, como no caso do rendimento em $1 / \mathrm{kg}$.

\subsection{Proteólise e durabilidade de queijos}

Queijos coagulados pela ação de ácido são geralmente consumidos frescos, mas a grande maioria dos queijos coagulados pela ação da renina são maturados por períodos variando de 4 semanas a mais de 2 anos; a duração da maturação é, em geral, inversamente proporcional ao conteúdo de umidade do queijo. Durante a maturação, um grande número de reações microbiológicas, químicas e bioquímicas ocorrem como resultado da degradação dos principais constituintes do queijo, como proteínas, lipídeos, e lactose residual. Os principais componentes que têm sido isolados de vários tipos de queijos são peptídeos, aminoácidos, aminas, ácidos, tióis, tioésters (advindos das proteínas), ácidos graxos, metil cetonas, lactonas e ésters (advindos dos lipídeos), ácidos orgânicos (ácido lático, acético e propiônico), dióxido de carbono, ésteres e álcoois (advindos da lactose). Em combinações adequadas, esses compostos são responsáveis pela caracterização do sabor e aroma dos diversos queijos (Fox, 1988). 


\subsubsection{Definição de proteólise}

Proteólise é, provavelmente, a mais importante transformação bioquímica durante a maturação para a maioria das variedades de queijo, com um maior impacto sobre o sabor, aroma e textura (Fox, 1989).

Segundo El Soda (1991), em geral, o processo de maturação envolve reações microbiológicas e químicas pelas quais o complexo das proteínas do leite é degradado a pequenos peptídeos e aminoácidos livres e os ésteres de ácidos graxos são convertidos em ácidos graxos livres (AGL).

A proteólise de um queijo é considerada como o resultado de várias atividades enzímicas (proteinase, peptidase) sendo que os principais contribuintes são a quimosina (renina, coalho) e as enzimas do fermento lático adicionadas ao leite no momento da fabricação do queijo. Outros microrganismos porventura presentes como resultado de contaminação causal, também podem contribuir para essa degradação (Wolfschoon-Pombo, 1983).

Quatro e, possivelmente, cinco agentes estão envolvidos na maturação do queijo: 1) coalho ou seus substitutos (ex: quimosina, pepsina ou proteinases microbianas), 2) enzimas próprias do leite, 3) fermento lático e suas enzimas, 4) enzimas da flora lática secundária (ex: bactérias ácido propiônicas, Brevibacterium linens; leveduras e fungos, tais como Penicillium roquefort e Penicillium candidum) são de grande importância em algumas variedades, 5) flora banal do leite (ex: microrganismos que sobrevivem à pasteurização do leite ou o contaminam após a pasteurização ou durante a fabricação do queijo; quando mortas, essas células rompem-se e liberam enzimas (Fox, 1989).

A proteólise no queijo pode ser dividida em três fases: proteólise no leite, antes da fabricação do queijo, na coagulação enzímica do leite; e a proteólise durante a maturação do queijo (Fox, 1989).

Várias categorias de enzimas proteolíticas são capazes de atuar 
conjuntamente na coalhada: o agente coagulante adicionado no momento da coagulação o qual permanece estável durante a maturação; as proteinases naturais do leite, as proteinases microbianas produzidas por bactérias láticas, e fungos como o Penicillium (P. camemberti ou $P$. roqueforti) e pela flora secundária (Choisy et al., 1986).

O Minas Frescal é um queijo consumido sem maturação, porém, a tecnologia de fabricação e conseqüentemente a proteólise, influenciam decisivamente na consistência, sabor e durabilidade do produto (Wolfschoon-Pombo \& Lima, 1989).

Quanto maior a proteólise em queijos, mais macia será sua consistência e seu aroma mais pronunciado. No queijo Minas Frescal, no entanto, uma proteólise avançada, caracterizada por uma cor amarelada da casca e uma consistência mole, são atributos negativos de sua qualidade (Wolfschoon-Pombo \& Lima, 1989).

\subsubsection{Efeitos do teor de sal e atividade de água}

A atividade proteolítica das enzimas é governada, parcialmente, pelo teor de sal (sal/umidade), já que o mesmo afeta o crescimento das bactérias presentes, através da atividade de água $\left(\mathrm{A}_{\mathrm{w}}\right)$ que proporciona (Wolfschoon-Pombo et al., 1984).

Dentre os componentes envolvidos na produção dos queijos, o sal tem papel marcante, pois além de conferir sabor à massa, auxilia no controle do crescimento e atividades microbianas, na atividade de várias enzimas no queijo, na saída do soro da massa e produz alterações físicas nas proteínas do queijo que influenciam na sua textura. Além de reduzir o teor de umidade, via sinerese, o sal é responsável pela diminuição da atividade de água dos queijos (Guinee \& Fox, 1984).

O teor de sal dos queijos influencia diretamente no seu sabor, mas possui também ação estimulante ou inibidora da ação enzimática dos microrganismos e de seu crescimento. Portanto, influencia também na textura dos queijos. Sabendo-se que o sal fica dissolvido na água livre do queijo, recomenda-se que seu controle seja efetuado em porcentagem sobre a umidade do queijo (Furtado, 1975). 
A atividade de água $\left(\mathrm{A}_{\mathrm{w}}\right)$ é um fator muito importante no crescimento microbiano e na ação de enzimas, exercendo grande influência na maturação. Diminuindo-se a atividade de água, reduz-se gradualmente a atividade enzimática; alonga-se a fase de latência de microrganismos e reduz-se seletivamente sua taxa de crescimento (Choisy et al., 1986).

Em um queijo, a atividade de água é determinada por dois parâmetros básicos, o conteúdo de água e o de sal. Também estão envolvidos o grau de maturação e o aumento do conteúdo de nitrogênio solúvel, sendo que este manifesta-se como um importante fator de redução na atividade de água. O conteúdo de umidade de um queijo representa um fator decisivo na maturação; queijos úmidos maturam mais rapidamente que aqueles que foram completamente drenados. A concentração de sal na fase aquosa também tem uma função importante. A maioria dos queijos encontra-se com teores de sal entre 4 e $5 \%$ e queijos Azuis alcançam de 6 a $8 \%$. Estas concentrações têm uma ação seletiva a nível microbiano e efeito inibitório sobre a atividade enzimática (Choisy et al., 1986).

Segundo Marcos et al. (1981), a atividade de água em queijos com teor de umidade acima de $40 \%$ pode ser determinada com precisão através de uma simples equação pré determinada, derivada da molalidade do cloreto de sódio $\left(\mathrm{A}_{\mathrm{w}}=1-0,033\right.$ M). Já em queijos com um teor de umidade abaixo de cerca de $40 \%$ a molalidade do cloreto de sódio não fornece bases para um cálculo preciso de atividade de água porque o efeito adicional de outros sólidos diminuem a atividade de água.

\subsection{3 Índices para avaliar a maturação de queijos}

A hidrólise da proteína pode ser quantificada por índices que relacionam o nitrogênio solúvel e o nitrogênio não protéico com o nitrogênio total, conhecidos como extensão (índice de maturação) e profundidade, respectivamente (Wolfschoon-Pombo, 1983). Pode-se afirmar que extensão da proteólise em queijos é sobretudo a ação proteolítica do coalho sobre as caseínas, principalmente nas frações $\alpha$ e $\beta$, aumentando o 
teor de peptídeos de médio e baixo peso molecular que compõem o nitrogênio solúvel (Choisy et al., 1986).

Para a quantificação das proteínas do queijo e, portanto, para a determinação da proteólise no mesmo, Gripon et al. (1975) descreveram técnicas de fracionamento do nitrogênio em extrato de queijo preparado com citrato de sódio 0,5 mol/litro, utilizando precipitações com ácido clorídrico e com ácido tricloroacético.

A extensão da proteólise caracteriza-se pela quantidade de substâncias nitrogenadas solúveis acumuladas durante o processo, expressas como porcentagens do nitrogênio total. Sua determinação analítica é baseada na precipitação da caseína até seu ponto isoelétrico ( $\mathrm{pH} 4,6)$. Assim, quando uma solução de queijo é trazida a $\mathrm{pH} 4,6$, as caseínas intactas, e também aquelas que se degradaram fracamente, são precipitadas. Peptídeos de alto peso molecular, peptídeos de cadeia curta e aminoácidos são encontrados nessa solução. Se for adicionado ácido tricloroacético a uma concentração final de $12 \%$ ao sobrenadante obtido após precipitação a $\mathrm{pH} 4,6$, mais peptídeos serão precipitados e somente peptídeos de cadeia curta e aminoácidos permanecerão na solução. Assim, a profundidade da proteólise abrange as substâncias nitrogenadas de baixo peso molecular, acumuladas durante o processo. Os peptídeos e aminoácidos das diferentes frações são geralmente quantificados após degradação do nitrogênio orgânico pela técnica de Kjeldhl (Choisy et al., 1986; Wolfschoon-Pombo, 1983).

O termo nitrogênio solúvel é geralmente usado para a fração de nitrogênio correspondente aos produtos que não são precipitados a pH 4,6 e nitrogênio não protéico para a fração que é solúvel em ácido tricloroacético (especificamente a uma concentração final de 12\%) (Choisy et al., 1986).

Foi desenvolvido por Vakaleris \& Price (1959) um método alternativo para o acompanhamento da proteólise em queijos baseado na determinação espectrofotométrica dos aminoácidos tirosina e triptofano. Esse método espectrofotométrico é um procedimento rápido para estimativa do grau de maturação de queijos. É mais ágil e tem uma exatidão aproximadamente igual às medidas de 
nitrogênio solúvel em um extrato de queijo pelo método de Kjeldahl. Segundo Fox (1988), a liberação desses aminoácidos é uma conseqüência da ação das enzimas do coalho e do fermento.

A presença de anel benzeno na estrutura desses aminoácidos e sua capacidade de absorção da luz ultravioleta, no comprimento de onda de 270 e $290 \mathrm{~nm}$, torna sua quantificação simples e um método eficiente de determinação de índice de proteólise em queijos. Os valores obtidos com a determinação espectrofotométrica do aminoácido tirosina, normalmente apresentam a mesma tendência daqueles índices de extensão e profundidade da maturação em queijos (Vakaleris \& Price, 1959).

\subsection{O uso de leite em pó na fabricação de queijos}

\subsubsection{Histórico}

Segundo Cherrey \& Lablée (1986), a idéia de utilizar leite em pó para a fabricação de queijo parece ter surgido com dois pesquisadores da Nova Zelândia, Hansen e Theophilus, em 1930. Entretanto, a aplicação industrial não teve início antes de 1950. A técnica tornou-se popular na França, onde a partir de 1952, grandes quantidades de leite em pó desnatado foram regularmente utilizadas para fabricar queijos moles. Até então, isso era meramente uma forma de substituição do leite desnatado reconstituído por leite desnatado fresco, com o intuito de regular os níveis de gordura de manteiga na mistura utilizada para a fabricação e assim remediar a estocagem de leite fresco no inverno em certas regiões leiteiras na França. Com bases nessas práticas, um processo para a fabricação de queijos duros a partir de leite reconstituído ou recombinado foi pesquisado no "National College of the Dairy Industry" em Mamirolle em 1958. Esse processo foi posto em prática em pequenas indústrias queijeiras estabelecidas em 1959, próximas de Teerã, no Irã. Parece provável que esta foi a primeira indústria de queijo destinada a trabalhar com leite reconstituído ou recombinado. A partir desse período, várias fábricas no mundo, tais como essa, estão em operação regular. 
Para Gilles et al. (1979), a história do queijo fabricado a partir de leite reconstituído data do início da década de 20 , quando tentou-se fabricar queijo Cottage em escala experimental. $O$ interesse em queijo fabricado com leite reconstituído intensificou-se com a II Guerra Mundial. Mas não foi antes do final da década de $50 \mathrm{e}$ início da década de 60 que a possibilidade de fabricar vários queijos com leite reconstituído recebeu mais atenção em muitos países.

\subsubsection{Justificativa}

Segundo Al-Tahiri (1987), as variações na produção de leite devido às estações do ano ou à baixa produção em certas regiões, conduziram a introdução da tecnologia de secagem para manter constante o abastecimento de leite em períodos e locais que fossem necessários. Dentro dos últimos 30 anos, ocorreu um aumento constante na quantidade de leite em pó vendido em áreas do mundo onde a demanda por leite fluido excede a quantidade disponível. O leite em pó é também particularmente adequado em países onde as condições climáticas e dificuldades de transporte influenciam de forma contrária o abastecimento de um produto fresco ao consumidor.

A fabricação de queijo a partir de leite recombinado às vezes é necessária em países ou regiões com abastecimento baixo ou flutuante de leite fresco ou com distâncias elevadas entre as áreas produtoras de leite e os centros de consumo de queijos. Assim, em países muito grandes, como o Brasil, onde as melhores regiões para produção de gado situam-se bastante longe das grandes cidades consumidoras e onde estradas de difícil condições de tráfego ligam essas regiões entre si, o transporte diário de centenas de toneladas de leite in natura é feito freqüentemente através de 1000 a $1500 \mathrm{Km}$. Assim, torna-se mais econômico transportar o leite sob forma de pó do que no estado líquido (Cherrey, 1977). Com o mesmo ponto de vista, Lablée (1979) afirma que diante dos resultados satisfatórios obtidos utilizando-se leite recombinado para a fabricação de queijos, essa tecnologia é recomendada para países com sazonalidade acentuada, ou para locais onde há laticínios insuficientes ou inexistentes para suprir a demanda por queijos. 


\subsubsection{Qualidade do leite em pó para a fabricação de queijo}

Muitas variedades de queijo podem ser fabricadas satisfatoriamente a partir de leite reconstituído usando leite em pó integral ou leite recombinado empregando-se leite em pó desnatado e gordura anidra. Para manter a coagualabilidade máxima, o leite em pó deve ser obtido principalmente de leite fresco que não tenha sido pré aquecido em temperatura acima de $72^{\circ} \mathrm{C}$ por 15 segundos ou $99^{\circ} \mathrm{C}$ por 1 segundo (Gilles \& Lawrence, 1981).

Dependendo do grau de aquecimento a que um leite é submetido no processamento do leite em pó, podem ocorrer vários graus de desnaturação das proteínas do soro e, conseqüentemente, pós de diferentes qualidades são obtidos. Com isso, é de interesse prático, tanto para o fabricante como para o industrial, saber o grau de desnaturação das proteínas para que se possa classificar os variados tipos de pós existentes.

A classificação de leite em pó baseia-se, segundo o "British Standard Methods for Analysis of Dried Milk and Dried Milk Products" (1983), na determinação das proteínas do soro desnaturadas, quando da aplicação de tratamento térmico na fabricação de leite em pó por vaporização, predominantemente no pré aquecimento do leite fluido. Esse aquecimento ocasiona um aumento das soroproteínas desnaturadas no leite (que tornam-se associadas à caseína) proporcional ao grau do tratamento témico aplicado. Os métodos para classificar o leite em pó envolvem a quantificação direta das proteínas do soro residuais não desnaturadas ou a determinação indireta das proteínas do soro desnaturadas.

O método mais amplamente utilizado é provavelmente aquele publicado pela American Dry Milk Institute (ADMI) (1971), no qual a concentração das soroproteínas nitrogenadas não desnaturadas no leite em pó é determinada turbimetricamente. Assim, o índice de nitrogênio de soroproteínas - WPNI (Whey Protein Nitrogen Index) - revela inforrnações sobre a desnaturação das soroproteínas durante o tratamento de pré aquecimento, evaporação e da secagem por vaporização do 
leite em pó. Através desse método, o leite em pó pode ser enquadrado em uma das seguintes classes de aquecimento: "low heat" (não menos que 6,0 mg/g), "medium heat" (1,51 mg a $5,99 \mathrm{mg} / \mathrm{g}$ ) ou "high heat" (não mais que $1,5 \mathrm{mg} / \mathrm{g}$ ).

Em geral, leite recombinado possui propriedades similares ao leite do qual o pó foi obtido. No processamento de leite em pó, entretanto, devido à desnaturação de proteínas, as propriedades da coagulação do leite recombinado são afetadas. Como a velocidade de coagulação e a firmeza do coágulo é um pré requisito na manufatura da maioria das variedades de queijo, o leite em pó desnatado usado na recombinação, deve ser do tipo "low heat", ou seja, WPNI não menor que $6,0 \mathrm{mg} / \mathrm{g}$ e preferencialmente não armazenado por mais de um ano (Gilles et al., 1979). Para Zuraw et al. (1985), as razões para isso, se devem ao fato de que esse tipo de pó contém mais cálcio ionizado e mais soroproteínas não desnaturadas que outros pós tratados com tratamento térmico severo.

Assim, para Gilles \& Lawrence (1981) e Zuraw et al. (1985), o mais importante fator na fabricação de queijo reconstituído é o tipo de pó empregado. Leite em pó "low heat" é essencial para a fabricação de todas as variedades de queijo a partir de leite reconstituído onde a coagulação é conduzida pela adição de coalho bovino ou enzimas de ação similar, pois a coagulabilidade do leite reconstituído é fortemente afetada pela extensão do aquecimento a temperaturas superiores a $60^{\circ} \mathrm{C}$ durante a manufatura do pó.

Segundo Al-Tahiri (1987), quando leite em pó integral é reconstituído com água em uma escala pequena, homogeneizadores portáteis manuais ou elétricos são adequados para tal procedimento. Em um laticínio, um equipamento padronizado, como um tanque de camisa dupla, que possui um agitador adequado para dissolver o pó na água, pode ser utilizado com bastante satisfação.

Segundo Sanderson (1979), o leite em pó integral não é utilizado tanto quanto o leite em pó desnatado na fabricação de produtos lácteos reconstituídos ou recombinados devido sua estabilidade relativamente pequena durante a estocagem. Entretanto, se for utilizado, deve ser de classificação fina, leite em pó integral secado por 
pulverização, com menos de nove meses de fabricação, produzido com a mínima padronização seguinte:

Umidade (máxima).

Acidez Titulável (em ácido láctico)

Índice de Solubilidade (máx.) método ADMI.

Partículas queimadas, método ADMI.

Contagem Global (máximo por grama)

Leveduras e mofos (máximo por grama)

Livre de sabores e odores estranhos
$3,00 \%$

$0,15 \%$

$0,1 \mathrm{ml}$

disco B ou melhor

50.000 ufc

$10 \mathrm{ufc}$

\subsubsection{Efeitos da utilização de leite em pó para a fabricação de queijos}

Em geral, pode-se obter um queijo de qualidade aceitável a partir de leite recombinado usando-se os mesmos princípios e padronização aplicados na produção de queijos fabricados com leite fresco. As perdas de gordura e caseína durante a fabricação não são maiores quando leite reconstituído é utilizado ao invés de leite fresco, contanto que uma emulsão estável seja obtida através de uma homogeneização eficiente dos ingredientes básicos (Gilles \& Lawrence, 1981).

Com o intuito de aplicar o processo convencional para a fabricação de queijo recombinado, é essencial a utilização de leites preparados com boa coagulabilidade e modificar ligeiramente os estágios da manufatura, onde quer que seja necessário (Mietton, 1988).

Muitas pesquisas mostram que em leite reconstituído, algumas das propriedades mais fundamentais do leite em relação à fabricação de queijo, ou seja, a coagulação e a sinerese, são prejudicadas. Essas mudanças são geralmente atribuídas à desnaturação de proteínas do soro pelo calor e à redução da atividade de íons cálcio (Zuraw et al., 1985). As adequações do processo são necessárias para compensar os efeitos do tratamento quente e da homogeneização sobre (a) firmeza do gel, (b) perda de umidade por sinerese e (c) propriedades funcionais do queijo (Gilles \& Lawrence, 1982). 


\subsubsection{Coagulabilidade}

O tratamento térmico tem um considerável efeito sobre a distribuição de cálcio no leite. Isso inevitavelmente afeta o tempo de coagulação pelo coalho, visto que o cálcio está envolvido na coagulação e na sinerese da coalhada (Gilles \& Lawrence, 1981).

Dentro desse mesmo contexto, Mietton (1988) aponta que leite recombinado exibe coagulabilidade fraca como resultado de (a) retrogradação irreversível de minerais ( $\mathrm{Ca}$ e $\mathrm{P}$ ), (b) nível variável de desnaturação das proteínas do soro e, (c) o tratamento de homogeneização. Portanto, a velocidade de coagulação é mais lenta e a firmeza do coágulo é menor. A coagulabilidade aumentada reduz perdas como finos durante o processo de coagulação.

É de conhecimento geral que, em leite fresco, o tempo de floculação e de coagulação é reduzido com o abaixamento do $\mathrm{pH}$ ou pela adição de cálcio. Dessa forma, alguns estudos apontam que, empregando-se relações similares em leite reconstituído, pode-se obter resultados satisfatórios.

Para ajudar o processo de coagulação, cloreto de cálcio ou fosfato de cálcio, às vezes acompanhado por ácido fosfórico, podem ser adicionados ao concentrado antes da secagem ou ao leite recombinado (Gilles et al., 1979). A adição de cerca de $20 \mathrm{~g}$ de cloreto de cálcio/100 1 leite reconstituído diretamente ao tanque de fabricação, melhora a uniformidade da velocidade de coagulação, firmeza final da coalhada, além de manter normal o tempo de coagulação (30-40 min) (Gilles \& Lawrence, 1981).

El-Ghandour et al. (1983a) obtiveram firmeza adequada da coalhada, na produção de queijo Ras a partir de leite recombinado, com acidez de 0,18\% e temperatura de coagulação de $40^{\circ} \mathrm{C}$, com adição de $0,05 \%$ de cloreto de cálcio e $3 \mathrm{ml}$ de coalho em solução 1\% / $50 \mathrm{ml}$ de leite; já Zuraw et al. (1985) obtiveram melhoria na coagulabilidade e sinerese em queijo Danbo adicionando-se ao leite reconstituído "low 
heat" $1,5 \mathrm{mM}$ de cálcio, ajustando o $\mathrm{pH}(6,45-6,50)$ e mantendo o leite reconstituído refrigerado a $5^{\circ} \mathrm{C}$ por 18 horas.

Resultados similares foram obtidos por Hassan \& El Deeb (1986) quando elevaram a temperatura de coagulação do leite recombinado a $40^{\circ} \mathrm{C}$ para fabricação de queijo Ras a fim de produzir coalhada com firmeza semelhante àquela obtida com o leite fresco. Além disso, foi adicionado cloreto de cálcio $(0,05 \%)$, cloreto de cálcio + fosfato dissódico $(0,15 \%)$, ou fosfato monocálcico ( $0,07 \%)$ e leite recombinado contendo fosfato monocálcico mantido sob refrigeração a $5^{\circ} \mathrm{C}$ por 12 horas. Os melhores resultados foram obtidos com queijo fabricado com adição de fosfato monocálcico mantido sob refrigeração. $\mathrm{O}$ rendimento de todos os queijos fabricados com leite recombinado foi maior do que aquele obtido com leite fresco.

\subsubsection{Sinerese e problemas de dessoragem}

A sinerese do coágulo obtido de leite reconstituído é freqüentemente afetada pela insolubilização das proteínas do soro (Mietton, 1988); a taxa de sinerese decresce ligeiramente (Gilles \& Laurence, 1982).

Em geral, coalhada obtida a partir de leite reconstituído tem tendência a reter mais umidade do que a coalhada de leite fresco. Para auxiliar a expulsão de umidade, temperaturas de cozimsnto mais altas podem ser usadas em queijos de massa cozida (Gilles et al., 1979; Zuraw et al., 1985).

Os inconvenientes da dessoragem podem ser resolvidos pela utilização de pó "low heat" ou "medium heat", ou através do enriquecimento do conteúdo de proteína do leite pela adição de ultrafiltrado ou pela adição de retentado em pó, caseinatos, etc., e/ou empregando temperatura de coagulação e cozimento mais altos (Mietton, 1988). 


\subsubsection{Rendimento}

As perdas de gordura associadas com a fabricação de queijos usando-se leite recombinado são geralmente menores que na fabricação normal de queijos, enquanto que as perdas de caseína são similares (Gilles \& Lawrence, 1982). O emprego de leite em pó desnatado com algum grau de proteínas do soro desnaturadas resultou em um aumento no rendimento de queijo Cottage acima de $10 \%$ devido a retenção de proteínas do soro no coágulo (Hammond, 1972). Igualmente, severo tratamento térmico de leite recombinado resultou em um maior aumento de rendimento no caso de queijos tipo Quarg (Pointurier, 1982). A adição de $0,15 \%$ de fosfato de sódio, $0,1 \%$ de citrato de sódio e $0,1 \%$ de $\mathrm{NaCl}$ ao leite recombinado aumentou o rendimento de queijo tipo Ras, melhorando seu corpo e textura (El-Ghabdour et al., 1983b).

Siapantas (1981) estudando o efeito da utilização de leite recombinado e concentrado por ultrafiltração na fabricação de queijo Feta (um dos queijos mais consumidos na Grécia), encontrou cerca de $30 \%$ de aumento no rendimento devido a incorporação de proteínas do soro e outros compostos, além de $80 \%$ na redução do coalho utilizado.

Hill et al. (1982), estudando os efeitos do pH, cloreto de cálcio e níveis de sólidos do leite sobre o rendimento, composição e qualidade do queijo "Queso Blanco", observaram que a recuperação de sólidos foi maior no queijo fabricado com leite integral do que naquele fabricado com leite reconstituído de composição similar. A acidez não teve efeito sobre a recuperação de sólidos a pH 5,5-4,9. A utilização de quantidade maior que $0,05 \%$ de cloreto de cálcio aumentou a umidade do queijo e a recuperação de sólidos, produzindo queijo com sabor amargo. Menor quantidade de cloreto de cálcio aumentou a recuperação de sólidos mas não afetou outros parâmetros. Leite recombinado com $15 \%$ de sólidos não gordurosos e 4,5\% de gordura resultou em Queso Blanco aceitável; $86 \%$ da proteína do leite foi recuperada.

Em queijo mole fabricado com leite de vaca fresco com a adição de $10 \mathrm{e}$ $20 \%$ de leite desnatado reconstituído, contendo $10 \%$ de sólidos totais (ST), observou-se 
que o conteúdo de gordura do leite cru com $10 \%$ de leite reconstituído desnatado foi significativamente mais alto do que aquele do leite com $20 \%$ de leite reconstituído desnatado. Os sólidos totais do leite cru seguiram a mesma tendência, embora a diferença não tenha sido estatisticamente significativa. A adição de leite em pó reconstituído não afetou as perdas de gordura no soro. O conteúdo de gordura do queijo macio foi significativamente afetado pelos tratamentos; $\mathrm{pH}, \%$ de umidade e conteúdo de sal não mostraram diferenças significativas, mas o rendimento decresceu com a adição de leite em pó reconstituído (Ranas Oliveros \& Dulay,1982).

Queijos Domiati foram fabricados com leite fresco com gordura ajustada a 3\% (controle) ou com leite fresco misturado com leite em pó integral reconstituído a $20,30,55$ ou $80 \%$. O teor de água, acidez titulável, $\mathrm{pH}$, e os teores de nitrogênio total e solúvel foram similares em todos os queijos durante a conservação, enquanto que o conteúdo de gordura teve uma tendência em decrescer com o aumento da adição do leite reconstituído. O rendimento mais alto foi do queijo fabricado com leite contendo $80 \%$ de leite reconstituído (21, 2 versus $18 \%$ no queijo controle). Entretanto, esse queijo teve a pontuação organoléptica mais baixa; o queijo fabricado com leite misturado com $55 \%$ de leite reconstituído foi considerado o melhor (Mashaly et al., 1983).

\subsubsection{Mudanças na maturação e desenvolvimento de sabor e aroma}

É aceito que, em geral, queijos fabricados com leite reconstituído maturam muito vagarosamente e desenvolvem sabor e aroma muito pouco pronunciados (Gilles et al., 1979; El-Ghabdour et al., 1983b; Czulak \& Hammond, 1974). Assim, alguns pesquisadores têm recomendado o uso, especialmente para as variedades de queijos duros, a adição de culturas, tais como, Streptococcus thermophilus, Lactobacillus acidophilus e particularmente L. casei, no intuito de produzir desenvolvimento de sabor e aroma mais rápido (Gilles et al., 1979).

Omar \& Buchheim (1983a) estudaram, de forma comparativa, a composição, microestrutura e qualidade organoléptica de queijos estilo Feta fabricados 
com leite em pó instantâneo reconstituído e com leite cru. As análises químicas nos queijos frescos e após 2 meses de maturação, mostraram grande similaridade, exceto para o teor de sal, que foi mais elevado em queijos de leite reconstituído ao final da maturação. A degradação protéica durante a maturação foi mais pronunciada nos queijos com leite cru. Os estudos com microscopia eletrônica, mostraram diferenças distintas na estrutura da matriz protéica nas amostras de queijos maturados, isto é, uma estrutura muito homogênea nos queijos feitos com leite cru, comparados com o estado ligeiramente agregado da proteína nos queijos feitos com leite reconstituído. Observações organolépticas revelaram uma aceitabilidade geral da qualidade dos queijos fabricados com leite reconstituído, exceto quanto ao teor de sal.

A maturação, e, com ela o desenvolvimento de sabor e aroma, tem sido mais lenta em queijos fabricados com leite recombinado (experimental), como o Gouda, onde a degradação protéica foi mais pronunciada no queijo controle do que no queijo experimental, sendo que a concentração de aminoácidos livres totais do queijo (experimental) e do controle foi de 167,7 e $226,0 \mathrm{mg} / 100 \mathrm{~g}$, respectivamente, após 4 semanas e 353,2 e 613,2 mg/100g após 8 semanas. O queijo experimental foi similar ao controle em aparência, coloração e consistência, mas apresentou um leve sabor salgado (Omar \& Buchheim, 1983b).

Mehanna et al. (1983) estudaram a proteólise de queijos moles fabricados com leite recombinado e concentrado por ultrafiltração utilizando técnicas eletroforéticas. Observou-se que a concentração de $\beta$-lactoglobulina diminuiu durante a conservação em salmoura diliuída por 90 dias, indicando sua suscetibilidade à proteólise. A $\alpha$-caseína foi degradada rapidamente durante este período, enquanto que a $\beta$-caseína foi relativamente resistente à proteólise.

Abd El Salam et al. (1983), variando o tipo de coalho e de fermento lático, na fabricação de queijo branco condimentado utilizando leite recombinado, não encontraram diferenças significativas nos níveis de nitrogênio solúvel e tirosina, variando-se o tipo de cultura lática adicionada, quando comparado ao queijo controle. 
No entanto, houve diferenças quanto ao tipo de coalho utilizado, sendo que níveis maiores foram encontrados com o emprego de coalho de bezerro e liofilizado.

Hagrass et al. (1983) estudaram o efeito de alguns agentes de maturação ( $0,02 \%$ de enzima lipase; coalho microbiano $-6,25 \mathrm{~g} / 100 \mathrm{Kg}$ leite); na produção de queijo Ras fabricado com leite recombinado tratado com fosfato dissódico. Não foram observadas diferenças marcantes sobre o $\mathrm{pH}$ dos queijos com os diferentes tratamentos de maturação. A adição de lipase aumentou claramente o teor de ácidos graxos voláteis totais, e componentes carbonilas saturados e insaturados, resultando em sabor e aroma de ranço.

Vários métodos têm sido investigados a fim de acelerar a maturação de queijos, onde o desenvolvimento de sabor e aroma ocorrem vagarosamente. $\mathrm{O}$ emprego de agentes de maturação (lipases com ou sem proteinases) resultou em uma taxa significativamente mais alta de produção de ácidos voláteis e formação de peptídios em queijo Ras recombinado do que no mesmo queijo de leite fresco, durante a maturação. Isso pode ser explicado sabendo-se que a desnaturação parcial das proteínas do leite durante o processamento do leite em pó e da remoção de glóbulos de gordura através de membranas, durante a fabricação de leite em pó desnatado, torna os queijos recombinados mais acessíveis aos agentes de maturação (El-Soda et al., 1988).

\subsubsection{Tipos de queijos específicos fabricados a partir de leite reconstituído}

A literatura especializada têm muitos relatos a respeito das possibilidades de fabricação dos mais variados tipos de queijos recombinados. Há estudos com queijos brancos sem maturação (Queso Blanco, Cottage), queijos moles com superfície coberta por fungos (Camembert), queijos de massa filada (Mussarela), queijos de massa semicozida prensados (Prato, Edam, Gouda, Cheddar, Danbo), queijos processados, queijos duros (Ras), queijos com crescimento de fungo internamente (Queijos Azuis, Gorgonzola). Todas as citações possuem em comum sugestões para adequações do processamento tradicional ao processamento com a utilização de leite reconstituído ou leite recombinado. 


\subsubsection{Queijos brancos sem maturação}

Ranas Oliveros \& Dulay (1982) estudando a qualidade de queijo mole fabricado com leite de vaca fresco, adicionado de 10 e $20 \%$ de leite desnatado reconstituído, contendo $10 \%$ de sólidos totais (ST), concluíram que a adição de leite em pó reconstituído não afetou significativamente as principais características para sabor, aroma, corpo, textura, coloração e aceitabilidade em geral.

Queijo mole tipo Travnik, foi obtido com êxito, a partir de leite recombinado empregando-se métodos convencionais; os queijos apresentaram qualidade muito boa, bastante semelhantes ao controle (Dozet et al., 1983).

O queijo "Queso Blanco" pode ser fabricado a partir de leite recombinado obtido de pós "low" ou "high-heat"; em ambos os casos o queijo resultante possui um conteúdo de umidade mais elevada e possui sabor e aroma mais pronunciado de ácido acético do que o queijo fabricado a partir de leite fresco (Gilles \& Lawrence, 1981). As condições ótimas para a obtenção do "Queso Blanco" de boa qualidade, fabricado a partir de leite em pó "low heat" e de creme fresco ( $35 \%$ de gordura), incluem o emprego de leite reconstituído com $3 \%$ de gordura, $15 \%$ de sólidos não gordurosos e o uso de $10 \%$ de solução de ácido cítrico monohidratado como coagulante, além da adição de sal (2,5\%) na massa (Hill et al., 1982).

O queijo Cottage tem sido obtido satisfatoriamente há vários anos nos Estados Unidos a partir de leite desnatado reconstituído, particularmente em períodos da estação em que o leite fresco está em fornecimento reduzido. Hammond (1972) ressalta que o grau de desnaturação das proteínas do soro tem uma influência significante no conteúdo de umidade do queijo Cottage e na sua qualidade final. Isso sugere que leite em pó "low heat" deve ser utilizado de preferência.

White \& Ryan (1983) estudaram as condições ótimas para fabricar queijos Cottage com leite reconstituído com vários níveis de sólidos totais (8-20\%) e $(10.5,12,13$ e $15 \%)$. O queijo fabricado com $10,5 \%$ de leite em pó desnatado 
reconstituído foi o melhor com relação a umidade, tempo de coagulação, custo, rendimento e aparência da coalhada.

\subsubsection{Queijos de massa semi-cozida}

Queijo Prato (Vieira \& Neves, 1980), Danbo (Zuraw et al., 1985) e Edam (Czulak \& Hammond, 1974) foram fabricados satisfatoriamente com leite reconstituído, possuindo textura, sabor e aroma aceitáveis.

Zuraw et al. (1985) adaptaram uma metodologia para a fabricação de queijo Danbo com leite recombinado, utilizando cultura lática e coalho em doses adicionais, aumentando as temperaturas de coagulação, de cozimento e o tempo de mexedura; a drenagem do soro e a adição de água foram realizadas duas vezes ao invés de uma só vez, com a finalidade de reduzir o conteúdo de lactose na coalhada mais eficientemente. Com essas pequenas modificações, esse método também foi usado para fazer queijos de mesma qualidade usando leite reconstituído misturado com 50 e $25 \%$ de leite comum. Nenhum problema de consistência ou de sabor e aroma foram encontrados.

\subsubsection{Mussarela}

Thompson (1978) descreveu a fabricação de queijo Mussarela utilizando leite em pó desnatado "low heat" e creme fresco como recurso de matéria gordurosa. Ele relatou propriedades normais de derretimento e elasticidade, mas ausência de desenvolvimento de sabor e aroma típicos. Nenhum defeito de sabor ou aroma atribuídos ao leite em pó foram, entretanto, encontrados. Em contraste, Gilles \& Lawrence (dados não publicados) observaram que as características de filagem do queijo Mussarela foram prejudicadas quando leite recombinado foi empregado. Alterações no derretimento e elasticidade foram observadas em todos os estágios durante a maturação do queijo (Gilles \& Lawrence, 1981).

Queijo Mussarela fabricado com leite recombinado normal não exibiu as características de elasticidade e derretimento de queijos fabricados com leite fresco. 
Nesse estudo demonstrou-se que esse problema pode ser superado com o uso de baixas pressões de homogeneização no preparo do leite recombinado (Lelievre et al., 1990).

\subsubsection{Queijo Azul}

Queijo Azul foi produzido com leite reconstituído e padronizado a 3,8\% de gordura, adicionando-se creme. Durante a maturação do queijo por 60 dias a $5^{\circ} \mathrm{C}$, houve aumento nos teores de gordura, proteína e sal no extrato seco, nitrogênio solúvel, ácidos graxos voláteis totais, ácidos graxos livres totais, e contagem de leveduras e fungos, mas diminuíram bactérias totais e lipolíticas, além de bactérias proteolíticas. Durante a maturação, a matriz caseínica tomou-se mais homogênea e o fungo Penicillium espalhou-se pelas olhaduras e reentrâncias, por entre e ao redor das partículas de caseína. Após 60 dias houve evidência clara de degradação do fungo e degeneração da hifa (El Zayat \& Omar, 1985).

Rabie et al. (1988) realizaram um estudo com queijo Azul fabricado com leite recombinado, variando-se duas linhagens de Penicillium roqueforti e a forma de salga (salmoura e salga seca). A maturação variou conforme a linhagem empregada e o tipo de salga utilizada, verificada pela análise dos níveis de nitrogênio solúvel, tirosina, triptofano, ácidos graxos voláteis e compostos carbonila. $\mathrm{O}$ nível desses compostos foram mais altos em queijos com salga seca do que naqueles salgados em salmoura, além de que os primeiros apresentaram melhor visual, melhor desenvolvimento da casca e menor crescimento fúngico superficial, além de sabor e aroma típicos do queijo Azul. 


\section{MATERIAL E MÉTODOS}

O experimento foi conduzido no Setor de Laticínios, do Departamento de Ciência e Tecnologia Agroindustrial, da Escola Superior de Agricultura "Luiz de Queiroz" - ESALQ/USP. Foram processados queijos tipo Minas Frescal adicionando-se vários níveis de leite reconstituído ao leite in natura.

Foram realizados 04 ensaios (repetições), com 04 tratamentos (níveis de $0,10,20$, e $40 \%$ de leite reconstituído adicionado ao leite in natura). Cada ensaio foi realizado num mesmo dia, obtendo-se queijos Minas Frescal a partir de 8 litros de leite.

As análises dos queijos foram realizadas após 4 períodos de armazenamento sob refrigeração a $\pm 8-10^{\circ} \mathrm{C}, \mathrm{em} \mathrm{D}+1, \mathrm{D}+7, \mathrm{D}+14$ e D + 21 dias, sendo "D" o dia da fabricação.

Foram avaliados os efeitos dos tratamentos e do tempo de armazenamento na composição dos queijos, além da avaliação de sua aceitabilidade.

\subsection{Matéria-prima}

\subsubsection{Leite in natura}

Utilizou-se, para a fabricação dos queijos, o leite bovino integral, pasteurizado pelo processo HTST $\left(72^{\circ} \mathrm{C}, 15\right.$ seg.), fornecido pela Agropecuária Santa Cruz Ltda., situado no município de Piracicaba, São Paulo. 


\subsubsection{Leite reconstituído}

Para obtenção de leite reconstituído, utilizou-se o leite em pó integral, proveniente da Nova Zelândia, "medium heat", fornecido pela importadora New Zealand Milk Products (São Paulo, SP).

\subsection{Coadjuvantes de processamento}

\subsubsection{Cloreto de cálcio}

$\mathrm{O}$ cloreto de cálcio $\left(\mathrm{CaCl}_{2}\right)$ foi utilizado na forma de solução aquosa, a 50\% (p.v.), na proporção de 20g por 100 litros de leite (Oliveira \& Caruso, 1996).

\subsubsection{Cloreto de sódio}

O cloreto de sódio $(\mathrm{NaCl})$ utilizado, foi o sal comum, de granulação fina, da marca registrada Cisne. Esse ingrediente foi adicionado diretamente ao leite, na proporção de $1,5 \%$ em relação ao volume deste.

\subsubsection{Cultura lática}

Adicionou-se ao leite a cultura láctica mesofilica, homofermentativa do tipo O, liofilizada e concentrada (DVS R-703), composta por Lactococcus lactis subsp. lactis e Lactococcus lactis subsp. cremoris, proveniente da Christian Hansen Ind. e Com. Ltda., (Valinhos, SP). A quantidade utilizada foi conforme recomendações do fabricante, equivalente a $1 \%$ de fermento lático tradicional.

\subsubsection{Agente coagulante}

O agente de coagulação empregado, foi o coalho em pó de origem bovina, fornecido pela Christian Hansen Ind. e Com. Ltda. (Valinhos, SP). Utilizou-se na 
proporção de $50 \mathrm{mg}$ para cada litro de leite, conforme especificações do fabricante, diluído em água destilada, previamente fervida e resfriada à temperatura ambiente (1g de coalho em pó diluído em $100 \mathrm{ml}$ de água).

\subsection{Técnica de reconstituição do leite em pó e mistura ao leite in natura}

Para preparar o leite reconstituído, o leite em pó integral foi adicionado lentamente, com auxílio de uma peneira, à superfície da água, previamente fervida, resfriada a $45^{\circ} \mathrm{C}$. A homogeneização foi manual, utilizando-se uma escumadeira de aço inoxidável, até completa dissolução do pó. O leite reconstituído foi mantido sob refrigeração por 16 horas, aproximadamente, para perfeita hidratação das proteínas (Vieira \& Neves, 1980).

No momento da fabricação do queijo, o leite reconstituído foi misturado ao leite in natura, nas proporções previamente definidas, diretamente na cuba de fabricação de queijos, com capacidade de 10 litros. Em seguida, homogeneizou-se e ajustou-se a temperatura a $37 \pm 1^{\circ} \mathrm{C}$ em equipamento com temperatura controlada.

\subsection{Técnica de fabricação do queijo Minas Frescal}

Para fabricação dos queijos, foram utilizados 08 (oito) litros de leite em cada tratamento, de acordo com a técnica recomendada por Furtado \& Lourenço-Neto (1994), com algumas modificações necessárias para obtenção de queijos similares àqueles fabricados somente com o leite fresco, como mostra a Figura 1. 

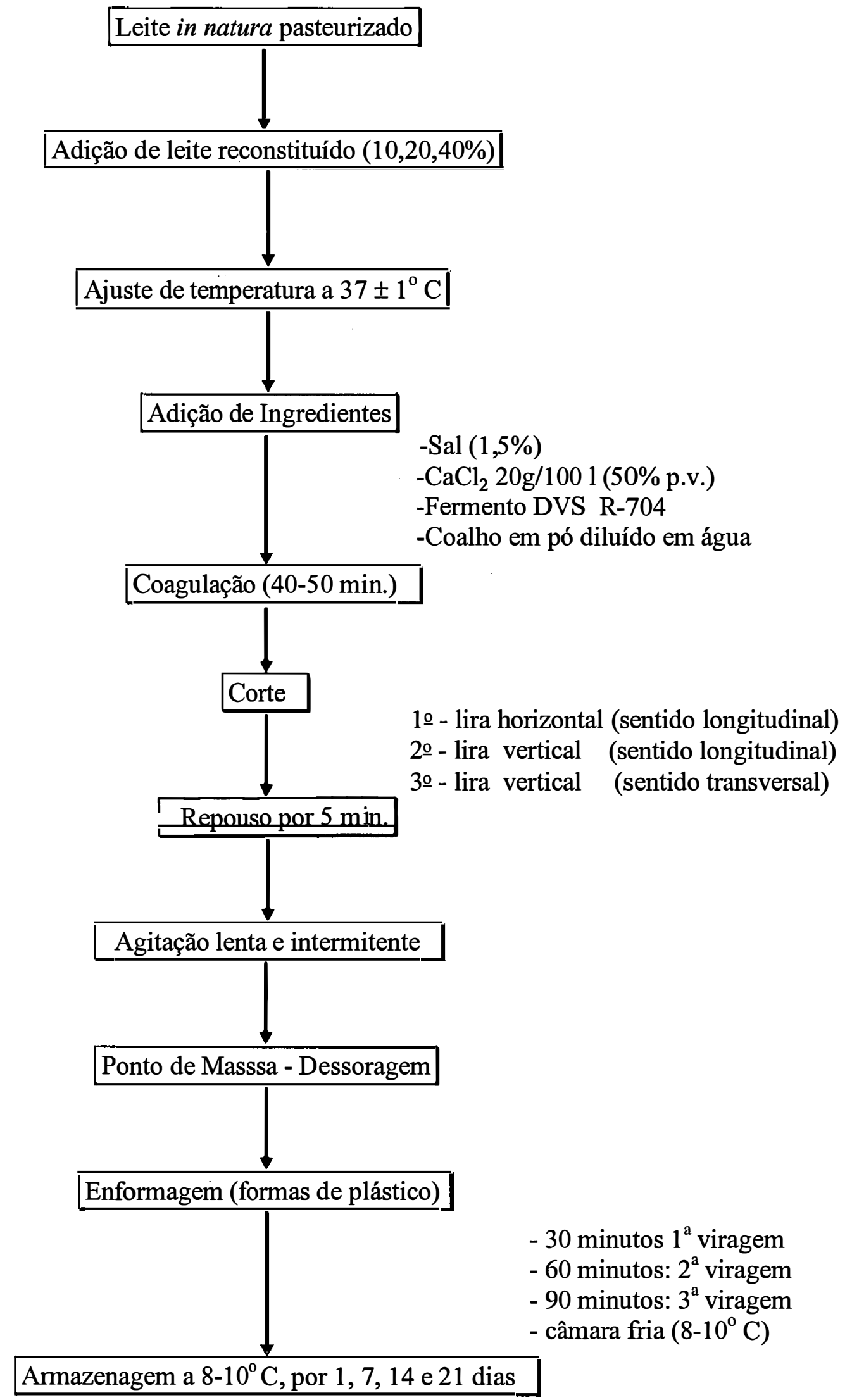

Figura 1 - Fluxograma de fabricação de queijo Minas Frescal com adição de leite reconstituído. 


\subsection{Análises físico-químicas do leite}

As amostras de leite foram coletadas após ter-se misturado o leite in natura ao leite reconstituído, antes de cada processamento, diretamente das cubas de fabricação de queijos, após ligeira homogeneização.

As determinações foram realizadas em duplicata.

\subsection{1 pH}

A determinação do $\mathrm{pH}$ do leite, foi realizada em potenciômetro digital com eletrodo de vidro da marca Digimed, modelo DMPH-2, previamente calibrado, segundo LANARA (1981).

\subsubsection{Acidez titulável}

Partindo-se de $10 \mathrm{ml}$ de amostras de leite, a acidez titulável foi determinada através de titulação com solução de hidróxido de sódio $(\mathrm{NaOH}) \mathrm{N} / 9$ (solução Dornic), tendo como indicador a solução alcoólica de fenolftaleína a 1,0\%. Os resultados foram expressos em Graus Dornic $\left({ }^{\circ} \mathrm{D}\right)$, segundo LANARA (1981).

\subsubsection{Densidade}

A densidade do leite foi determinada pela leitura direta a $15^{\circ} \mathrm{C}$, utilizando-se o termolactodensímetro de Quevenne, segundo LANARA (1981).

\subsubsection{Extrato seco total (EST)}

A determinação do extrato seco total do leite foi realizado segundo o método da A.O.A.C. (1995), baseado na técnica de secagem em estufa a $105^{\circ} \mathrm{C}$ por 3 horas e pesagem até peso constante. 


\subsubsection{Gordura}

O teor de gordura do leite, foi determinado pelo método de Babcock (A.O.A.C., 1995; Newlander \& Atherton, 1964). Utilizou-se, para tal análise, uma centrífuga do tipo Babcock.

\subsubsection{Proteína}

O teor de proteína do leite foi determinado pelo Método Kjeldahl, (técnica do micro Kjeldahl), segundo IDF- International Dairy Federation (1962), diretamente sobre $0,14-0,16 \mathrm{~g}$ do leite.

\subsubsection{Desnaturação das proteínas de soro do leite}

A determinação da porcentagem de desnaturação das proteínas de soro do leite foram determinadas no leite in natura pasteurizado e na mistura leite in natura + leite reconstituído a 10,20 e $40 \%$. Todas as amostras foram desnatadas em centrífuga (Fanem, modelo 204-NR), por 10 minutos a $4 \times 10^{3} \mathrm{rpm}$.

As amostras de leite $(15 \mathrm{ml})$, após serem precipitadas na presença de $6 \mathrm{~g}$ de $\mathrm{NaCl}$ por meia hora em banho-maria a $37^{\circ} \mathrm{C}$, foram filtradas (papel Whatman $\mathrm{n}^{\mathrm{o}} 42$ ) $\mathrm{e}$ $1 \mathrm{ml}$ do filtrado foi diluído em $10 \mathrm{ml}$ de solução saturada de sal, com adição de 2 gotas de $\mathrm{HCl}$ (23:77), registrando-se, em seguida, a transmitância no comprimento de onda 420 $\mathrm{nm}$, conforme técnica descrita por Harland \& Ashworth (1947).

\subsection{Análises físico-químicas do soro}

As amostras de soro foram coletadas diretamente da cuba de fabricação dos queijos, após a retirada da massa, depois de homogeneização. 
As determinações de $\mathrm{pH}$, acidez titulável, densidade, extrato seco total, gordura e proteína foram realizadas segundo as metodologias descritas nos itens 3.5.1, 3.5.2, 3.5.3, 3.5.4, 3.5.5, 3.5.6, sendo feitas em duplicata.

\subsection{Cálculos das porcentagens de transição de gordura e sólidos totais do leite para o queijo}

As cifras de transição de elementos do leite para o queijo (gordura e sólidos totais) foram obtidas considerando-se as perdas de constituintes no soro, de acordo com Folegatti (1994), da seguinte forma:

a) o volume de leite empregado em cada processamento de queijo foi obtido através da medição em proveta apropriada;

b) a massa do leite foi calculada multiplicando-se o volume de leite pela sua densidade;

c) a quantidade de gordura ou de sólidos totais presentes no leite foi obtida multiplicando-se o volume total de leite pela sua quantidade percentual;

d) a massa do soro foi obtida subtraindo-se a massa do leite da massa dos queijos obtidos;

e) a massa do soro foi dividida pela sua densidade, resultando no volume total, que foi então multiplicado pela percentagem de gordura ou sólidos totais, obtendo-se a quantidade dos constituintes perdidos no soro;

f) foi feita a relação entre o volume de gordura ou sólidos totais do soro e o volume de gordura ou sólidos totais do leite, obtendo-se, assim, as perdas dos constituintes no soro;

g) o resultado obtido foi subtraído de 100, obtendo-se a transição do constituinte para o queijo. 


\subsection{Cálculos de rendimento de fabricação}

Os rendimentos das fabricações dos queijos foram calculados de duas formas, como indicados a seguir:

a) Litros de leite por quilo de queijo na mesma base úmida (1 leite/kg queijo)

Os rendimentos expressos em 1 leite/kg de queijo na mesma base úmida foram obtidos multiplicando-se a massa de queijo (P) obtida em cada fabricação (em kg) por um valor de umidade fixo (60) seguindo-se da divisão pela umidade real (U), previamente determinada. Dividiu-se, então, o volume de leite (V) empregado em cada fabricação pelo valor anteriormente encontrado.

A fórmula seguinte poderá também ser utilizada:

$$
\mathrm{R}=\frac{100 \times \mathrm{V}}{\mathrm{P} \times 6 \% / \mathrm{U}}
$$

b) Gramas de sólidos totais de queijo por litro de leite (g ST/1 leite)

Para expressar o rendimento das fabricações em gramas de sólidos totais de queijo por litro de leite trabalhado, os seguintes cálculos foram feitos:

Multiplicou-se os quilos de queijos obtidos (P) em cada tratamento pela percentagem de extrato seco total dos mesmos (ST), obtendo-se a massa de sólidos totais presentes no queijo. Esse valor encontrado, dividido pelo volume de leite (V) empregado na fabricação dos queijos, obtém-se o rendimento em gramas de ST de queijo/litro de leite. A seguinte fórmula pode ser utilizada:

$$
\mathrm{g} \mathrm{ST} / 1 \text { leite }=\frac{\mathrm{P} \times \mathrm{ST} \times 10}{\mathrm{~V}}
$$




\subsection{Análises físico-químicas do m̧ueijo}

As amostragens dos queijos foram tomadas utilizando-se faca de aço inoxidável com lâmina pontiaguda, fazendo-se cortes perpendiculares, de acordo com as especificações da Association of Official Agricultural Chemists (A.O.A.C., 1995).

O preparo das amostras foi feito cortando-as em tiras, picando-as e misturando-as perfeitamente (A.O.A.C., 1995).

As determinações foram realizadas em duplicata.

Um dia após a fabricação, foram realizadas as análises fisico-químicas dos queijos, determinando-se seu teor umidade, gordura, gordura no extrato seco, teor de sal, atividade de água, sal na água do queijo e proteína total.

O acompanhamento da vida de prateleira dos queijos teve início um dia após a fabricação dos queijos (em D + 1) e em intervalos de 7 dias (aos $7^{\circ}, 14^{\underline{0}}$ e $21^{\circ}$ dias) com análises de $\mathrm{pH}$, acidez titulável, teor de tirosina, nitrogênio total, além de nitrogênio solúvel em pH 4,6 e em solução TCA 12\% para a determinação dos índices de extensão e profundidade de maturação, respectivamente.

\subsection{1 pH}

A determinação do $\mathrm{pH}$ do queijo, foi realizada em potenciômetro digital com eletrodo de vidro, da marca Digimed, modelo DMPH-2, previamente calibrado, segundo LANARA (1981), inserindo-se o eletrodo em uma solução aquosa do queijo devidamente macerado.

\subsubsection{Acidez titulável}

Partindo-se de $10 \mathrm{~g}$ de amostra de queijo, adicionou-se água a $40^{\circ} \mathrm{C}$ até completar volume para $100 \mathrm{ml}$; agitou-se vigorosamente. Após filtração, $25 \mathrm{ml}$ do 
filtrado foram titulados com $\mathrm{NaOH} 0,1 \mathrm{~N}$, tendo como indicador a solução alcoólica de fenolftaleína a $1,0 \%$. Os resultados foram expressos em porcentagem de ácido lático, de acordo com as descrições da A.O.A.C. (1995).

\subsubsection{Umidade}

A determinação do teor de umidade do queijo foi realizada segundo o método da A.O.A.C. (1995), baseado na técnica de secagem em estufa a $98-100^{\circ} \mathrm{C}$ por 3 horas e pesagem até peso constante. O conteúdo de umidade foi expresso em porcentagem ( $\mathrm{g} / 100 \mathrm{~g}$ de amostra).

\subsubsection{Gordura}

$\mathrm{O}$ teor de gordura das amostras de queijo foi determinado pelo método de Babcock, utilizando-se uma centrífuga do tipo babkock (A.O.A.C., 1995; Newlander \& Atherton, 1964).

\subsubsection{Gordura no extrato seco (GES)}

O teor de gordura no extrato seco (GES) do queijo foi obtido pela seguinte relação:

$$
\mathrm{GES}=\frac{\% \text { de gordura }}{\% \text { de extrato seco total }} \times 100
$$

\subsubsection{Cloreto de sódio}

O teor de sal do queijo foi determinado pelo método de Volhard, modificado por Pereira (1975), titulando-se o excesso de nitrato de prata com tiocianato de potássio $0,1 \mathrm{~N}$. O teor de cloreto de sódio foi expresso em porcentagem (g de $\mathrm{NaCl} / \mathrm{g}$ de amostra). 


\subsubsection{Sal na umidade do queijo}

O teor de sal na umidade do queijo foi determinado pela fórmula:

$$
\% \text { sal na umidade }=\frac{\% \text { sal }}{\% \text { sal }+\% \text { umidade }} \times 100
$$

\subsubsection{Atividade de água $\left(\mathrm{A}_{\mathrm{w}}\right)$}

A atividade de água do queijo foi obtida mediante a fórmula de Esteban \& Marcos (1990), a qual correlaciona teor de sal e sal na umidade do queijo:

$$
A_{w}=1-0,033 M
$$

Sendo,

$\mathrm{M}=$ molalidade do $\mathrm{NaCl}$

Matematicamente simplificado,

$\mathrm{M}=\left[(\mathrm{g} \mathrm{NaCl} \times 1000) / \mathrm{g} \mathrm{H}_{2} \mathrm{O}\right) / 58,5$

\subsubsection{Nitrogênio total (NT) e proteína total (PT)}

O teor de nitrogênio total (NT) do queijo foi determinado pelo método Kjeldahl, diretamente sobre uma alíquota de $5 \mathrm{ml}$, extraída em citrato de sódio $0,5 \mathrm{M}$, segundo Gripon et al. (1975). As amostras foram digeridas em Blocos Digestores modelo - TE 008/50, e destiladas em destilador modelo TE-036.

A porcentagem de proteína total (PT) do queijo foi calculada, multiplicando-se os valores médios de porcentagem de nitrogênio total pelo fator 6,38. 


\subsubsection{Fracionamento do nitrogênio total}

\subsubsection{Nitrogênio solúvel a pH 4,6}

O teor de nitrogênio solúvel (NS) do queijo foi determinado após precipitação isoelétrica das caseínas com solução de ácido clorídrico 1,41 N até pH 4,6, em uma amostra de queijo, previamente solubilizada em citrato de sódio $0,5 \mathrm{M}$. Essa mistura foi filtrada em papel de filtro Whatman $\mathrm{n}^{\mathbf{0}} 42$, coletando-se uma solução límpida, contendo a fração hidrolisada da proteína do queijo, solúvel a pH 4,6. A quantificação dessas substâncias solúveis foi através do método de Kjeldahl, partindo-se de $5 \mathrm{ml}$ do filtrado (Gripon et al., 1975; Vakaleris \& Price, 1959).

\subsubsection{Nitrogênio não protéico solúvel em TCA $12 \%$}

As amostras de queijo previamente solubilizadas em citrato de sódio 0,5 $\mathrm{M}$, foram precipitadas em solução final $12 \%$ com ácido tricloroacético (TCA) e filtradas em papel de filtro Whatman $\mathrm{n}^{0} 42$, coletando-se uma solução límpida, a qual continha peptídeos de baixo peso molecular e aminoácidos (Vakaleris \& Price, 1959). O nitrogênio contido nessa solução é denominado nitrogênio não protéico e foi quantificado pelo método Kjeldahl, partindo-se de $5 \mathrm{ml}$ do filtrado (Gripon et al., 1975).

\subsubsection{Cálculo dos índices de extensão e profundidade da proteólise}

Os métodos e fórmulas seguidos são de acordo com as citações de Furtado \& Partridge (1988) e Wolfschoon-Pombo (1983).

Índice de Extensão: relação entre a porcentagem de nitrogênio solúvel a pH 4,6 (obtido como descrito em 3.9.10.1) e a porcentagem de nitrogênio total (descrito em 3.9.9).

$$
\text { Extensão da Proteólise }=\frac{\text { Nitrogênio Solúvel }}{\text { Nitrogênio Total }} \times 100
$$


Índice de Profundidade: relação entre a porcentagem de nitrogênio não protéico, solúvel em TCA a 12\%, (obtido como descrito em 3.9.10.2) e a porcentagem de nitrogênio total (3.9.9).

$$
\text { Profundidade da proteólise }=\frac{\text { Nitrogênio Não Protéico }}{\text { Nitrogênio Total }} \times 100
$$

\subsubsection{2 Índice de tirosina}

O teor de tirosina foi obtido segundo a metodologia proposta por Vakaleris \& Price (1959) para a determinação do índice de maturação de queijos. A fração solúvel obtida como descrita no item 3.9.10.1, foi diluída em água destilada na proporção 1:1 e submetida à leitura em dois comprimentos de onda, 270 e $290 \mathrm{~nm}$, em espectrofotômetro, modelo B-382.

A concentração do aminoácido (mg/100g de queijo), foi calculada pela

fórmula:

$$
\operatorname{Tyr}=\left(0,95 \times \mathrm{A}_{270}-1,31 \times \mathrm{A}_{290}\right) 906
$$

sendo,

$\mathrm{A}_{270}=$ Leitura da absorbância a $270 \mathrm{~nm}$;

$\mathrm{A}_{290}=$ Leitura da absorbância a $290 \mathrm{~nm}$

\subsubsection{Análise sensorial}

A avaliação sensorial foi realizada dois dias após a fabricação dos queijos (em D+2); os queijos foram mantidos sob refrigeração $\mathrm{a} \pm 8-10^{\circ} \mathrm{C}$, embalados em sacos plástios impermeáveis. As amostras foram servidas à temperatura ambiente. Foram apresentadas aos provadores amostras de queijos de todos os tratamentos, em formato retangular de $2,5 \times 1 \times 1 \mathrm{~cm}$.

Os queijos foram avaliados quanto a sua aceitabilidade de acordo com Mori (1982), utilizando escala hedônica não estruturada de 9 pontos. O painel de 
degustadores foi compostos por 50 pessoas não treinadas.

O modelo de ficha apresentado aos degustadores para a avaliação sensorial encontra-se ao final desta parte (Figura 2).

\subsection{Análise estatística}

Os resultados obtidos, tanto das análises físico-químicas como das análises sensoriais, foram submetidos à análise estatística. Foi adotado o delineamento experimental Blocos ao Acaso, com quatro tratamentos (Testemunha, 10\%, 20\%, e 40\% de leite reconstituído adicionado ao leite in natura) e 4 repetições (blocos). Os dados foram avaliados através do Teste $\mathrm{F}$ da Análise da Variância e Teste Tukey. Para o cálculo dos dados, foi utilizado o programa "SAS" (Pimentel-Gomes, 1985).

O esquema de Análises de Variância para as análises físico-químicas foi o seguinte:

\begin{tabular}{lc}
\hline \hline CAUSAS DE VARLAÇÃO & GRAUS DE LIBERDADE \\
\hline Blocos & $\mathbf{3}$ \\
Tràtamento & $\mathbf{3}$ \\
Resíduo & $\mathbf{9}$ \\
\hline TOTAL & $\mathbf{1 5}$ \\
\hline \hline
\end{tabular}


Nome:

Data:

Você está recebendo amostras de queijo Minas Frescal. Prove-as, por favor, e indique a sua preferência, assinalando nas escalas abaixo, respectivamente.

Em seguida, responda as questões.

Amostra no

Desgostei

Gostei

Muitíssimo

Muitíssimo

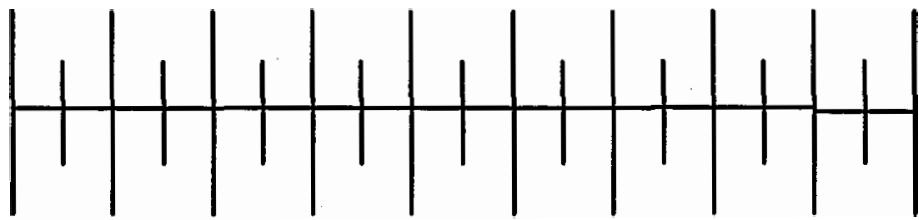

Amostra no

Desgostei

Gostei

Muitíssimo

Muitíssimo

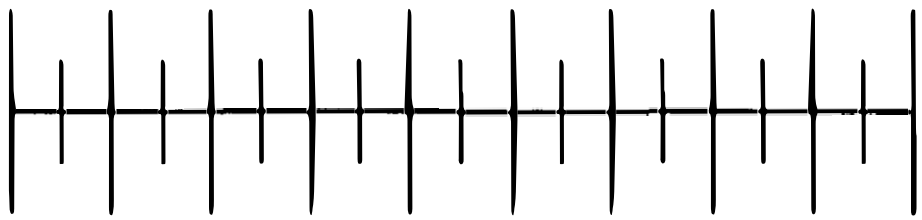

Amostra $\mathbf{n}^{0}$

Desgostei Gostei

Muitíssimo Muitíssimo

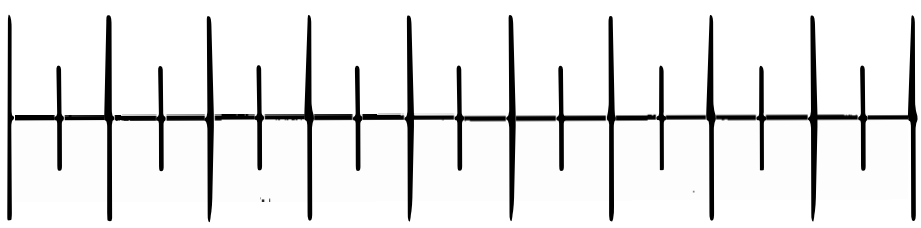

Amostra no

Desgostei

Gostei

Muitíssimo

Muitíssimo

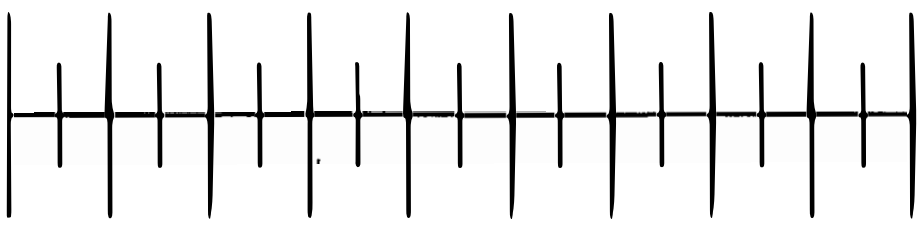

Figura 2 - Ficha de avaliação sensorial apresentada aos degustadores. 


\section{RESULTADOS E DISCUSSÃO}

\subsection{Composição físico-química do leite}

A Tabela 1 apresenta os resultados médios da composição físico-química do leite in natura (controle) e com a adição de 10, 20 e 40\% de leite reconstituído, empregados no processamento dos queijos. Observou-se que os valores obtidos são semelhantes aos encontrados na literatura para o leite sem adição de leite reconstituído (Furtado et al., 1980; Vieira \& Neves, 1980; Wolfschoon-Pombo et al., 1978) e estão dentro dos limites estabelecidos pela legislação (Brasil, 1980).

Tabela 1. Resultados médios da composição físico-química dos leites utilizados para a fabricação dos queijos.

\begin{tabular}{lccccc}
\hline & \multicolumn{4}{c}{ Leite reconstituído adicionado ao leite in natura (\%) } \\
\cline { 2 - 5 } \multicolumn{1}{c}{ Parâmetros } & 0 & 10 & 20 & 40 & C.V. \\
\hline $\mathrm{pH}$ & $6,77^{\mathrm{a}}$ & $6,66^{\mathrm{a}}$ & $6,77^{\mathrm{a}}$ & $6,67^{\mathrm{a}}$ & 1,78 \\
Acidez ( $\left.{ }^{\mathrm{o}} \mathrm{D}\right)$ & $16,29^{\mathrm{a}}$ & $16,36^{\mathrm{a}}$ & $16,68^{\mathrm{ab}}$ & $17,26^{\mathrm{b}}$ & 1,57 \\
Gordura (\%) & $3,24^{\mathrm{a}}$ & $3,05^{\mathrm{a}}$ & $3,04^{\mathrm{a}}$ & $2,99^{\mathrm{a}}$ & 2,97 \\
Proteína (\%) & $3,29^{\mathrm{a}}$ & $3,28^{\mathrm{a}}$ & $3,28^{\mathrm{a}}$ & $3,29^{\mathrm{a}}$ & 1,98 \\
Sólidos Totais (\%) & $11,95^{\mathrm{a}}$ & $12,00^{\mathrm{a}}$ & $12,02^{\mathrm{a}}$ & $12,02^{\mathrm{a}}$ & 0,88 \\
Densidade (g/ml) & $1,0320^{\mathrm{a}}$ & $1,0319^{\mathrm{a}}$ & $1,0322^{\mathrm{a}}$ & $1,03225^{\mathrm{a}}$ & 0,03 \\
\hline
\end{tabular}

Médias de quatro fabricações. a, b, c Médias com o mesmo expoente, na mesma linha, não são significativamente diferentes $(p<0,01)$. C.V $=$ Coeficiente de variação. 
Como a composição físico-química do leite influencia diretamente na composição final do queijo, as variações observadas no leite empregado nos diferentes dias de processamento, foram também responsáveis, em parte, pelas variações na composição dos queijos dos diferentes tratamentos.

No entanto, observa-se que mesmo com a adição de leite reconstituído ao leite in natura, não ocorreram variações significativas $(p<0,01)$ quanto à composição físico-química do leite reconstituído. Isso se deve ao fato da reconstituição do leite em pó integral ter sido realizada balanceando-se os elementos de sua composição ao teor de sólidos não gordurosos que se desejava obter; nesse caso, determinou-se obter um leite reconstituído com $8,75 \%$ de teor de sólidos não gordurosos.

Ocorreu um ligeiro aumento (até cerca de $1^{\circ} \mathrm{D}$ ) na acidez titulável nas misturas leite reconstituído + leite in natura, quando comparados ao leite in natura (controle). É possível que essa variação se deva à própria acidez do leite em pó, eventualmente superior àquela do leite in natura.

\subsection{Desnaturação protéica do leite}

São apresentados na Tabela 2 os resultados relativos às porcentagens de desnaturação das proteínas do soro, obtidos por método "salting-out", ou seja, através da precipitação de proteínas com cloreto de sódio seguida da determinação da transmitância em espectrofotômetro. Os valores das porcentagens de desnaturação têm uma tendência em aumentar proporcionalmente à medida que se adiciona leite reconstituído ao leite in natura, indicando que ocorre, de fato, desnaturação no leite em pó devido ao tratamento térmico ao qual foi submetido para sua obtenção.

Mesmo sendo um leite em pó classificado como "medium heat", pode-se concluir pelos dados da Tabela 2 que certamente ocorreu desnaturação parcial de proteínas em seu processamento. $\mathrm{O}$ grau de desnaturação do leite reconstituído irá influenciar nas características físico-químicas dos queijos obtidos, já que a $\beta$ lactoglobulina tende a precipitar-se sobre a fração da $\kappa$-caseína, formando agregados que 
retardam a coagulação, aumentando a retenção de água no queijo, com efeitos óbvios na sua característica e no processo de maturação (hidrólise protéica).

Tabela 2. Resultados médios da porcentagem de desnaturação das proteínas do soro, dos leites empregados para a elaboração dos queijos.

\begin{tabular}{lccccc}
\hline & \multicolumn{4}{c}{ Leite reconstituído adicionado ao leite in natura (\%) } \\
\cline { 2 - 5 } Determinação & 0 & 10 & 20 & 40 & C.V. \\
\hline $\begin{array}{l}\text { \% de desnaturação } \\
\text { das proteínas do soro }\end{array}$ & $7,06^{\mathrm{a}}$ & $12,94^{\mathrm{b}}$ & $18,83^{\mathrm{c}}$ & $29,88^{\mathrm{d}}$ & 11,97 \\
\hline
\end{tabular}

Médias de quatro fabricações. a, b, c Médias com o mesmo expoente, na mesma linha, não são significativamente diferentes $(p<0,01) . C . V=$ Coeficiente de variação.

\subsection{Processamento do queijo}

\subsubsection{Ingredientes adicionados ao leite}

Os ingredientes adicionados ao leite, de modo geral, foram os mesmos e nas mesmas dosagens daqueles utilizados na fabricação tradicional de queijos Minas Frescal. Assim, o emprego de $20 \mathrm{~g} / 100$ litros de leite de cloreto de cálcio foi similar às quantidades comumente adicionadas na fabricação desse queijo com leite in natura (Furtado \& Lourenço-Neto, 1994; Oliveira \& Caruso, 1996; Wolfschoon-Pombo et al., 1978) e também similar aos adicionados em fabricações de outros tipos de queijos com leite reconstituído (Gilles \& Lawrence, 1981; Hassan \& El Deeb, 1986; Zuraw et al., 1985), tendo por finalidade promover coagulação e sinerese normais.

O sal adicionado diretamente ao leite, a 1,5\%, não é uma prática comum, embora tenha se adotado essa forma de salga para controlar melhor esse fator de interação sobre a proteólise do queijo. A quantidade adicionada foi calculada para ser correspondente aos processos de salga na massa ou em salmoura e para se obter queijos com teor mediano de sal (1,0 - 1,5\%). 
Quanto à cultura lática mesófila, tipo $\mathrm{O}$, composta por Lactococcus lactis subsp. lactis e Lactococcus lactis subsp. cremoris, foi utilizada na proporção de $1 \% \mathrm{em}$ relação ao leite.

A quantidade de coalho em pó adicionado foi determinada a fim de obterse a coagulação do leite in natura em cerca de 40 a 50 minutos.

A temperatura de coagulação adotada no processamento dos queijos foi de $37^{\circ} \mathrm{C} \pm 1$, um pouco acima daquela empregada em certos laticínios $\left(35^{\circ} \mathrm{C}\right)$, de modo a compensar a menor coagulabilidade quando se utiliza leite reconstituído, segundo testes preliminares.

\subsubsection{Coagulação e agitação}

A técnica de fabricação do queijo Minas Frescal foi a mesma sugerida por Furtado \& Lourenço-Neto (1994). Procurou-se adotar os mesmos procedimentos, tanto para o queijo controle ( $0 \%$ de leite reconstituído) como para os queijos fabricados com adições de leite reconstituído (10, 20 e $40 \%)$. No entanto, foram realizadas algumas modificações durante o processamento, como o momento de corte da massa e o tempo de agitação da massa, a fim de obter-se queijos similares ao controle, quanto às características físico-químicas, como ilustrado na Tabela 3. Observou-se um período maior para o início da floculação do leite e, conseqüentemente, um tempo maior para a sua coagulação, quando aumentavam-se as quantidades de leite reconstituído adicionadas ao leite in natura, o que influenciaram diretamente no momento do corte $\mathrm{e}$ no tempo de agitação.

O tempo de coagulação foi maior no queijo fabricado com a adição de $40 \%$ de leite reconstituído ao leite in natura, embora não tenha sido estatisticamente diferente $(p<0,01)$. No entanto, o tempo de agitação foi diferente $(p>0,01)$ para cada tratamento (Tabela 3). Para que a massa atingisse o ponto de enformagem, foi preciso um período maior de agitação, à medida que adicionavam-se maiores doses de leite reconstituído ao leite in natura, variando de 32,50 a 53,75 minutos. A alteração desses 
fatores são atribuídos à adição de leite reconstituído, que prejudica a coagulabilidade e a sinerese da massa (Gilles \& Lawrence, 1982; Mietton, 1988; Zuraw et al., 1985). Isso se deve à desnaturação protéica que ocorre no leite no momento de sua desidratação; a desnaturação das proteínas do soro modifica a coagulação do leite e as propriedades reológicas da coalhada formada por acidificação ou por enzimas, implicando em maior resistência ao ataque enzimático da renina na א-caseína (Parry Jr., 1974). Assim, a formação da coalhada é mais difícil e também ocorre maior retenção de água pela soroproteína. Esse fato foi explicado por Hardy (1986), quando demonstrou que essas proteínas desnaturadas têm maior capacidade de ligar-se à água do que à paracaseína, particularmente em atividades de água mais elevadas. Portanto, quando um leite é aquecido em excesso, o suficiente para insolubilizar as proteínas do soro e for destinado à fabricação de queijos, haverá como resultado um aumento da quantidade de água ligada no queijo.

Tabela 3. Tempos de floculação, coagulação e agitação observados durante as fabricações dos queijos.

\begin{tabular}{cccccc}
\hline & \multicolumn{4}{c}{ Leite reconstituído adicionado ao leite in natura (\%) } & \\
\cline { 2 - 5 } Tempo (minutos) & 0 & 10 & 20 & 40 & C.V. \\
\hline Tempo de Floculação & $11,75^{\mathrm{a}}$ & $11,75^{\mathrm{a}}$ & $12,25^{\mathrm{a}}$ & $13,5^{\mathrm{a}}$ & 9,21 \\
Tempo de Coagulação & $51,00^{\mathrm{a}}$ & $50,50^{\mathrm{a}}$ & $55,75^{\mathrm{a}}$ & $60,75^{\mathrm{a}}$ & 8,74 \\
Tempo de Agitação & $32,5^{\mathrm{a}}$ & $36,25^{\mathrm{ab}}$ & $44,25^{\mathrm{b}}$ & $53,75^{\mathrm{c}}$ & 7,18 \\
\hline
\end{tabular}

Médias de quatro fabricações. ${ }^{\text {a, b, c }}$ Médias com o mesmo expoente, na mesma linha, não são significativamente diferentes $(\mathrm{p}<0,01)$. C.V $=$ Coeficiente de variação.

\subsection{Composição do queijo}

Os dados das composições físico-químicas dos queijos fabricados com a adição de $0,10,20$ e $40 \%$ de leite reconstituído ao leite in natura, um dia após a fabricação dos queijos, estão dispostos na Tabela 4. 
Tabela 4. Composição fisico-química média dos queijos um dia após a fabricação.

\begin{tabular}{lccccc}
\hline & \multicolumn{4}{c}{ Leite reconstituído adicionado ao leite in natura (\%) } & \\
\cline { 2 - 5 } \multicolumn{1}{c}{ Determinações } & 0 & 10 & 20 & 40 & C.V. \\
\cline { 2 - 5 } $\mathrm{pH}$ & $5,52^{\mathrm{a}}$ & $5,65^{\mathrm{a}}$ & $5,46^{\mathrm{a}}$ & $5,68^{\mathrm{a}}$ & 5,70 \\
Acidez (\% ác.lático) & $0,56^{\mathrm{a}}$ & $0,46^{\mathrm{a}}$ & $0,59^{\mathrm{a}}$ & $0,65^{\mathrm{a}}$ & 32,11 \\
Umidade (\%) & $57,31^{\mathrm{a}}$ & $59,50^{\mathrm{ab}}$ & $60,06^{\mathrm{bc}}$ & $62,67^{\mathrm{c}}$ & 1,74 \\
Proteína Total (\%) & $15,76^{\mathrm{a}}$ & $14,98^{\mathrm{ab}}$ & $14,83^{\mathrm{b}}$ & $13,93^{\mathrm{b}}$ & 3,25 \\
GES (\%) & $50,59^{\mathrm{a}}$ & $49,93^{\mathrm{a}}$ & $45,85^{\mathrm{b}}$ & $43,46^{\mathrm{b}}$ & 3,01 \\
Teor de sal (\%) & $1,05^{\mathrm{a}}$ & $1,01^{\mathrm{a}}$ & $1,05^{\mathrm{a}}$ & $1,15^{\mathrm{a}}$ & 7,59 \\
Teor de sal na água & $1,80^{\mathrm{a}}$ & $1,67^{\mathrm{a}}$ & $1,72^{\mathrm{a}}$ & $1,80^{\mathrm{a}}$ & 7,20 \\
$\mathrm{~A}_{\mathrm{w}}$ & $0,990^{\mathrm{a}}$ & $0,990^{\mathrm{a}}$ & $0,990^{\mathrm{a}}$ & $0,990^{\mathrm{a}}$ & $10^{-6}$ \\
\hline
\end{tabular}

a, b, c Médias com o mesmo expoente, na mesma linha, não são significativamente diferentes $(\mathrm{p}<0,01)$. Médias de quatro fabricações. C.V. $=$ Coeficiente de Variação.

Não foram observadas maiores variações na acidez titulável e no $\mathrm{pH}$ dos queijos (Tabela 4) fabricados com adição de leite reconstituído ao leite in natura quando comparados ao queijo controle. Os valores encontrados são similares àqueles observados na literatura em queijo Minas Frescal (Furtado et al., 1980; Wolfschoon-Pombo et al., 1978), concluindo-se que a adição de leite reconstituído ao leite in natura não alterou esses parâmetros nos queijos, um dia após sua fabricação.

Os teores de umidade dos queijos, apresentados na Tabela 4, aumentaram com o incremento de leite reconstituído adicionado ao leite in natura $(\mathrm{p}>0,01)$, o que é uma conseqüência da maior retenção de água pelas soroproteínas desnaturadas pelo calor (Hardy, 1986; Gallina \& Brandão, 1996), provavelmente carreadas para o queijo.

A gordura no extrato seco (GES) diminuiu em seus valores absolutos; no entanto, essa diminuição é apenas aparente, pois na verdade, quando se converte todas as porcentagens de umidade em um só valor, por exemplo, igual ao do controle (sem adição 
de leite reconstituído), o teor de proteínas aumentará com o aumento de leite reconstituído adicionado ao leite in natura, e assim, o teor de gordura será mais baixo.

Os teores de sal encontrados nesse trabalho foram semelhantes aos valores encontrados por Saito \& Schiftan (1978) em 20\% de amostras de queijos Minas Frescal (maior percentagem de amostras) coletadas no mercado do Estado de São Paulo.

Devido à grande semelhança dos parâmetros relativos ao teor de sal $\mathrm{e}$ atividade de água $\left(\mathrm{A}_{\mathrm{w}}\right)$ dos queijos, considerou-se esses parâmetros serem de pouca relevância sobre a proteólise no queijo. $\mathrm{O}$ baixo teor de sal na água do queijo determinado após um dia da fabricação poderia, inclusive, ter um efeito estimulador na atividade proteolítica do coalho residual (Hardy, 1986), o que ocorreria então em todos os processos adotados, devido a similaridade dos resultados observados.

\subsection{Composição do soro}

Através das análises físico-químicas do soro, é possível avaliar as perdas de constituintes do leite durante a fabricação dos queijos. Esses dados, juntamente com os da composição do leite, fornecem bases para se determinar a quantidade de componentes que ficaram retidos na coalhada.

Os resultados apresentados na Tabela 5, mostram que os diferentes tratamentos praticamente não alteraram a composição físico-química do soro. Assim, a adição de leite reconstituído ao leite in natura, não implicou em maiores perdas de constituintes do leite no soro. Esses valores estão em concordância com resultados encontrados na literatura na fabricação de queijo Minas Frescal (Furtado et al., 1980; Rossi, 1997; Wolfschoon-Pombo et al., 1978). O fato da densidade do soro mostrar-se superior à literatura, pode ser explicado por ter-se adicionado o sal diretamente ao leite, refletindo em sua elevação, sendo que valores similares foram obtidos por Rossi (1997), quando utilizou a mesma técnica em seu estudo.

Observou-se ainda um ligeiro aumento da acidez titulável e do $\mathrm{pH}$ do soro nos queijos fabricados com adição de leite reconstituído ao leite in natura. Embora 
não sendo significativos estatisticamente $(\mathrm{p}<0,01)$, ambos são conseqüência da fermentação mais intensa ocorrida eventualmente naqueles processos em que o tempo de coagulação foi mais longo (Tabela 3). A elevação da acidez titulável do soro é também conseqüência da maior acidez titulável observada no leite reconstituído (Tabela 1). Pela Tabela 5, pode-se observar uma menor perda de gordura no soro nas fabricações utilizando-se leite reconstituído. Observou-se também menor perda de proteína no soro do queijo fabricado com $40 \%$ de leite reconstituído adicionado ao leite in natura, demonstrando que ocorre um maior carreamento de proteínas quando se utiliza leite reconstituído. Essa redução de perdas irá influenciar positivamente no rendimento dos queijos, como pode ser observado na Tabela 6 .

Tabela 5. Resultados médios da composição físico-química dos soros resultantes das fabricações dos queijos dos diferentes tratamentos.

\begin{tabular}{lccccc}
\hline & \multicolumn{4}{c}{ Leite reconstituído adicionado ao leite in natura (\%) } \\
\cline { 2 - 5 } \multicolumn{1}{c}{ Parâmetros } & 0 & 10 & 20 & 40 & C.V. \\
\hline pH & $6,51^{\mathrm{a}}$ & $6,49^{\mathrm{a}}$ & $6,44^{\mathrm{a}}$ & $6,49^{\mathrm{a}}$ & 0,72 \\
Acidez ( $\left.{ }^{\mathrm{O} D}\right)$ & $10,74^{\mathrm{a}}$ & $10,90^{\mathrm{a}}$ & $11,03^{\mathrm{a}}$ & $11,42^{\mathrm{a}}$ & 5,35 \\
Gordura (\%) & $0,30^{\mathrm{a}}$ & $0,26^{\mathrm{a}}$ & $0,28^{\mathrm{a}}$ & $0,25^{\mathrm{a}}$ & 11,57 \\
Proteína (\%) & $1,06^{\mathrm{a}}$ & $1,02^{\mathrm{a}}$ & $1,01^{\mathrm{a}}$ & $0,95^{\mathrm{b}}$ & 1,95 \\
Sólidos Totais (\%) & $8,18^{\mathrm{a}}$ & $8,26^{\mathrm{a}}$ & $8,29^{\mathrm{a}}$ & $8,25^{\mathrm{a}}$ & 0,78 \\
Densidade (g/ml) & $1,0380^{\mathrm{a}}$ & $1,0385^{\mathrm{ab}}$ & $1,0388^{\mathrm{ab}}$ & $1,0396^{\mathrm{b}}$ & 0,05 \\
\hline
\end{tabular}

Média de quatro fabricações. ${ }^{\text {a, b, c }}$ Médias com o mesmo expoente, na mesma linha, não são significativamente diferentes $(\mathrm{p}<0,01)$. C.V. $=$ Coeficiente de Variação.

\subsection{Rendimento do queijo}

Estão apresentadas na Tabela 6, as cifras de transição de gordura e de sólidos totais, representando a porcentagem de elementos que passaram do leite para $\mathrm{o}$ queijo. É notável que houve maior retenção de gordura, nos queijos fabricados com adição de leite reconstituído ao leite in natura, embora não tenha sido estatisticamente 
significativo $(\mathrm{p}<0,01)$. Isso porque as perdas de gordura associadas à fabricação de queijos com leite reconstituído, geralmente são menores (Gilles \& Lawrence, 1982), como pode ser verificado na Tabela 5. O aproveitamento de sólidos totais seguiu a mesma tendência; no entanto, nesse caso, foi estatísticamente significativo ( $p>0,01)$, resultando em aumento de rendimento de queijo, devido à retenção de soroproteínas no coágulo (Hammond, 1972; Pointier, 1982; Hill et al., 1982).

Tabela 6. Rendimento médio das fabricações dos queijos.

\begin{tabular}{|c|c|c|c|c|c|}
\hline \multirow[b]{2}{*}{ Parâmetros } & \multicolumn{4}{|c|}{ Leite reconstituído adicionado ao leite in natura (\%) } & \multirow[b]{2}{*}{ C.V. } \\
\hline & 0 & 10 & 20 & 40 & \\
\hline $\begin{array}{c}\text { Transição de Gordura } \\
(\%)\end{array}$ & $92,29^{\mathrm{a}}$ & $93,41^{\mathrm{a}}$ & $92,55^{\mathrm{a}}$ & $93,20^{\mathrm{a}}$ & 1,11 \\
\hline $\begin{array}{c}\text { Transição de ST } \\
(\%)\end{array}$ & $42,39^{\mathrm{a}}$ & $42,88^{\mathrm{ab}}$ & $42,92^{\mathrm{ab}}$ & $44,18^{b}$ & 1,81 \\
\hline $\begin{array}{l}\text { Rendimento mesma } \\
\text { base úmida }(60 \%)\end{array}$ & $6,00^{\mathrm{a}}$ & $5,85^{\mathrm{a}}$ & $5,81^{\mathrm{a}}$ & $5,57^{\mathrm{a}}$ & 2,57 \\
\hline $\begin{array}{l}\text { Rendimento em } \\
\text { g de ST/1 }\end{array}$ & $67,86^{\mathrm{a}}$ & $68,34^{\mathrm{a}}$ & $68,84^{\mathrm{a}}$ & $70,00^{\mathrm{a}}$ & 2,50 \\
\hline
\end{tabular}

Os dados de rendimento em gramas de sólidos totais por litro de leite ( $\mathrm{g}$ ST/l) comprovam que a transição maior de sólidos, conseqüente da maior transição de gordura e da maior incorporação de soroproteínas na coalhada (Tabelas 1 e 6), resultante da sua desnaturação, fazem com que se produza progressivamente mais gramas de sólidos totais com menos litros de leite à medida que se adicionam leite reconstituído ao leite in natura. Da mesma forma, os dados de rendimento na mesma base úmida (Tabela 6), confirmam o maior aproveitamento dos componentes do leite pelos queijos elaborados com leite reconstituído; assim, gasta-se progressivamente menor volume de leite para se produzir um quilo de queijo, com o mesmo teor de umidade. 


\subsection{Acompanhamento da vida de prateleira do queijo}

A acidez e o pH de queijos são atributos importantes na aceitabilidade de queijo Minas Frescal, sendo necessária sua relação com outros fatores como índices de proteólise e testes sensoriais (Rossi, 1997). Assim, o acompanhamento do $\mathrm{pH}$, da acidez titulável, da extensão da proteólise, da profundidade da proteólise e do teor de tirosina, realizados neste trabalho, foram meios de avaliação da durabilidade dos queijos elaborados.

\subsubsection{Evolução do pH do queijo}

A Tabela 7 e a Figura 3 apresentam dados da evolução do $\mathrm{pH}$ dos queijos, obtidos um dia após a fabricação dos queijos $(\mathrm{D}+1)$ e a cada sete dias durante 3 semanas (D+7, D+14, D+21). Observa-se em todos os tratamentos diminuição do valor do $\mathrm{pH}$ dos queijos devido à fermentação da lactose. As diferenças observadas foram pequenas, sem maiores conseqüências práticas e não foram significativas $(p<0,01)$. A evolução do $\mathrm{pH}$ foi acompanhada pelo aumento correspondente da acidez titulável, expressa em porcentagem de ácido lático.

Tabela 7. Evolução do pH dos queijos durante o armazenamento.

Leite reconstituído adicionado ao leite in natura (\%)

\begin{tabular}{lccccc}
\cline { 3 - 5 } $\begin{array}{l}\text { Dias após a } \\
\text { Fabricação }\end{array}$ & 0 & 10 & 20 & 40 & C.V. \\
\hline $\mathrm{D}+1$ & $5,52^{\mathrm{a}}$ & $5,65^{\mathrm{a}}$ & $5,46^{\mathrm{a}}$ & $5,68^{\mathrm{a}}$ & 5,70 \\
$\mathrm{D}+7$ & $5,28^{\mathrm{a}}$ & $5,30^{\mathrm{a}}$ & $5,24^{\mathrm{a}}$ & $5,23^{\mathrm{a}}$ & 1,17 \\
$\mathrm{D}+14$ & $5,11^{\mathrm{a}}$ & $5,19^{\mathrm{a}}$ & $5,17^{\mathrm{a}}$ & $5,05^{\mathrm{a}}$ & 1,43 \\
$\mathrm{D}+21$ & $5,21^{\mathrm{a}}$ & $5,17^{\mathrm{a}}$ & $5,15^{\mathrm{a}}$ & $5,08^{\mathrm{a}}$ & 1,43 \\
\hline
\end{tabular}

Médias de quatro fabricações. ${ }^{a, b}$, c Médias com o mesmo expoente, na mesma linha, não são significativamente diferentes $(p<0,01) . C . V=$ Coeficiente de variação. 


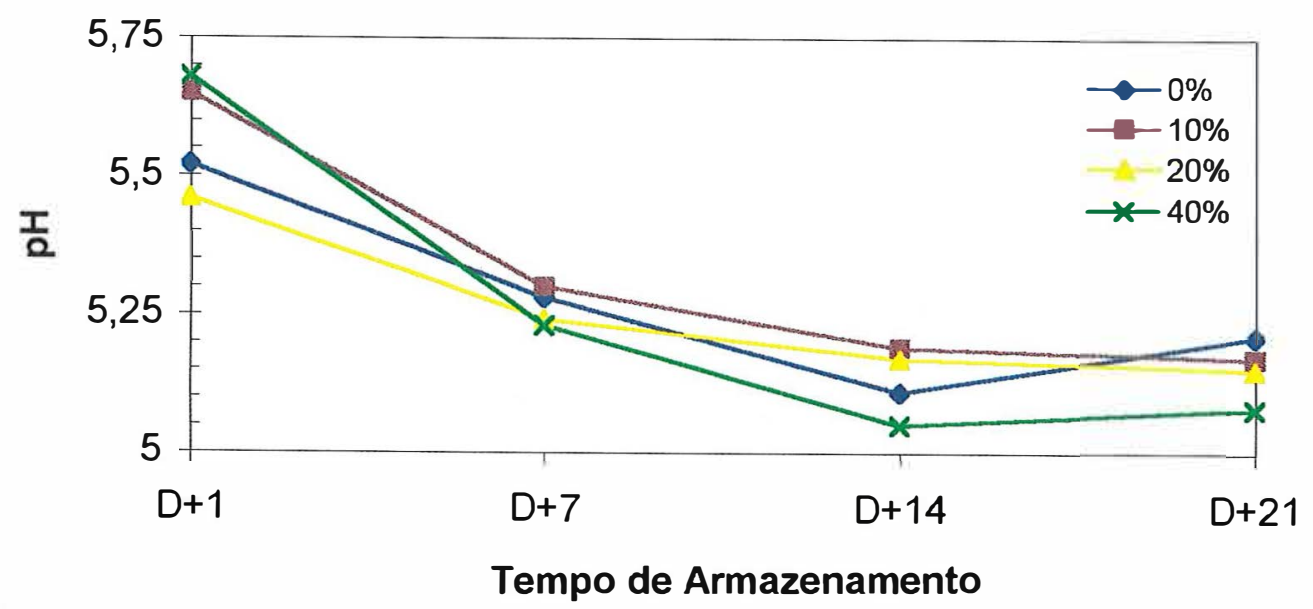

Figura 3 - Evolução do pH dos queijos, após 1, 7, 14 e 21 dias da fabricação, com $0,10,20$ e $40 \%$ de leite reconstituído adicionado ao leite in natura.

Os valores de $\mathrm{pH}$ encontrados foram superiores aos valores encontrados por Casagrande \& Wolfschoon-Pombo (1988), 4,96, 4,79, 4,58 em 1, 6 e 14 dias após a fabricação de queijos, respectivamente. No entanto, esses valores foram semelhantes aos encontrados por Wolfschoon-Pombo et al. (1978).

\subsubsection{Evolução da acidez titulável do queijo}

Estão apresentados na Tabela 8 e na Figura 4 a evolução da acidez titulável dos queijos obtidos após um dia $(\mathrm{D}+1)$ e aos 7, 14 e 21 dias após a fabricação dos queijos $(\mathrm{D}+7, \mathrm{D}+14, \mathrm{D}+21)$. Observa-se em todos os tratamentos um aumento da acidez titulável devido à fermentação da lactose, que desaparece nos primeiros dias de estocagem. A partir daí, a acidez tende a estabilizar-se. Não houve diferença significativa entre os tratamentos $(\mathrm{p}<0,01)$.

Os teores de ácido lático nos diferentes períodos de armazenamento foram inferiores aos encontrados por Casagrande \& Wolfschoon-Pombo (1988), 0,97 e $1,12 \%$ de ácido lático, um e seis dias após a fabricação dos queijos, respectivamente. 
Mas, 14 dias após a fabricação dos queijos, os teores de ácido lático foram semelhantes (0,99\%ácido lático).

Segundo Wolfschoon-Pombo et al. (1984), a velocidade de formação e a quantidade de ácido lático produzido influenciam a qualidade do queijo, além de regular o pH e o equilíbrio iônico, que é muito importante na formação de lactato de cálcio e inibição do crescimento de patógenos potenciais.

Tabela 8. Evolução da acidez tiluável dos queijos, expressa em porcentagem de ácido lático, durante o armazenamento.

\begin{tabular}{lccccc}
\hline & \multicolumn{4}{c}{ Leite reconstituído adicionado ao leite in natura (\%) } & \\
\cline { 2 - 5 } \multicolumn{1}{c}{$\begin{array}{c}\text { Dias após a } \\
\text { Fabricação }\end{array}$} & 0 & 10 & 20 & 40 & \multirow{2}{*}{ C.V. } \\
\hline D+1 & $0,5618^{\text {a }}$ & $0,4643^{\text {a }}$ & $0,5938^{\text {a }}$ & $0,6448^{\text {a }}$ & 32,11 \\
D+7 & $0,9168^{\text {a }}$ & $0,8815^{\text {a }}$ & $1,0130^{\text {a }}$ & $1,0013^{\text {a }}$ & 9,52 \\
D+14 & $0,9975^{\text {a }}$ & $0,8860^{\text {a }}$ & $0,9000^{\text {a }}$ & $1,0093^{\text {a }}$ & 10,38 \\
D+21 & $0,8648^{\text {a }}$ & $0,8978^{\text {a }}$ & $0,9068^{\text {a }}$ & $0,9978^{\text {a }}$ & 6,56 \\
\hline
\end{tabular}

${ }^{\mathrm{a}, \mathrm{b}, \mathrm{c}}$ Médias com o mesmo expoente, na mesma linha, não são significativamente diferentes ( $\left.\mathrm{p}<0,01\right)$. Médias de quatro fabricações. C.V = Coeficiente de variação.

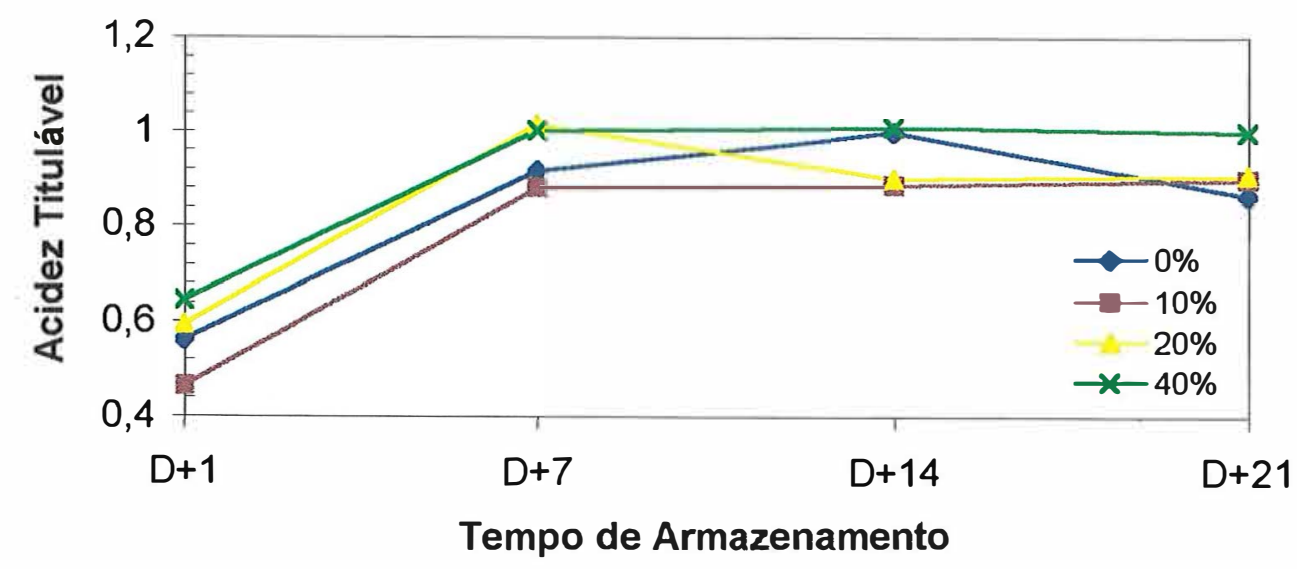

Figura 4 - Evolução da acidez titulável dos queijos, após 1, 7, 14 e 21 dias da fabricação, com $0,10,20$ e $40 \%$ de leite reconstituído adicionado ao leite in natura. 
A formação do ácido lático é essencial para o sabor do queijo Minas Frescal, bem como para sua qualidade e vida de prateleira. Entretanto, um excesso na produção de ácido lático pode conduzir a um sabor muito ácido no queijo (Casagrande \& Wolfschoon-Pombo et al., 1988), e descaracterizar o produto.

\subsubsection{Extensão da proteólise}

A Tabela 9 e a Figura 5 mostram as alterações nas frações nitrogenadas observadas no queijo Minas Frescal durante o armazenamento a $8-10^{\circ} \mathrm{C}$ por 21 dias; esses dados estão de acordo com a literatura para esse tipo de queijo fabricado com leite fresco (Wolfschoon-Pombo et al., 1984). Observa-se que há uma significativa diferença entre os índices de extensão da maturação ao longo do tempo, devido a um aumento progressivo da solubilização protéica (em $\mathrm{pH} 4,6$ ), sobretudo por ação do coalho. Entretanto, não há diferenças significativas entre os tratamentos $(\mathrm{p}<0,01)$. As proteínas do soro, carreadas para os queijos adicionados de leite reconstituído, não são degradadas, não interferindo, portanto, na proteólise dos mesmos (Mehanna et al., 1983). Além disso, o teor de sal na água do queijo e a atividade de água $\left(\mathrm{A}_{\mathrm{w}}\right)$, que interferem na proteólise dos queijos, são praticamente idênticos (Tabela 4) em todos os tratamentos.

Os índices de extensão da proteólise obtidos nesse trabalho, foram superiores àqueles encontrados por Wolfschoon-Pombo et al. (1978) em um dia após a fabricação dos queijos $(6,95)$, mas inferiores após seis dias de armazenamento $(13,63)$. No entanto, os dados encontrados após sete dias de armazenamento, foram semelhantes $(10,4)$ aos encontrados por Wolfschoon-Pombo (1983).

Notou-se ainda, pela Tabela 9, que os índices de proteólise dos queijos no período de D+1 para D+7 têm um aumento médio de 34,30\%, que aliado a um aumento médio $69,74 \%$ da acidez titulável dos queijos (Tabela 8) nesse mesmo período, reflete uma descaracterização da consistência e sabor e aroma do queijo Minas Frescal, tornando-o inadequado para o consumo ao atingir 7 dias de armazenamento. 
Tabela 9. Índices de extensão da proteólise dos queijos durante o armazenamento.

\begin{tabular}{lccccc}
\hline & \multicolumn{4}{c}{ Leite reconstituído adicionado ao leite in natura $(\%)$} & \\
\cline { 2 - 5 } $\begin{array}{l}\text { Dias após a } \\
\text { Fabricação }\end{array}$ & 0 & 10 & 20 & 40 & C.V. \\
\cline { 1 - 4 } D+1 & $7,59^{\mathrm{a}}$ & $7,63^{\mathrm{a}}$ & $7,19^{\mathrm{a}}$ & $7,40^{\mathrm{a}}$ & 2,23 \\
$\mathrm{D}+7$ & $10,32^{\mathrm{a}}$ & $9,62^{\mathrm{a}}$ & $9,72^{\mathrm{a}}$ & $10,28^{\mathrm{a}}$ & 8,22 \\
$\mathrm{D}+14$ & $13,55^{\mathrm{a}}$ & $12,07^{\mathrm{a}}$ & $11,67^{\mathrm{a}}$ & $11,93^{\mathrm{a}}$ & 6,88 \\
$\mathrm{D}+21$ & $13,03^{\mathrm{a}}$ & $13,79^{\mathrm{a}}$ & $13,11^{\mathrm{a}}$ & $13,97^{\mathrm{a}}$ & 2,63 \\
\hline
\end{tabular}

${ }^{a, b, c}$ Médias com o mesmo expoente, na mesma linha, não são significativamente diferentes $(\mathrm{p}<0,01)$. Médias de quatro fabricações. C.V = Coeficiente de variação.

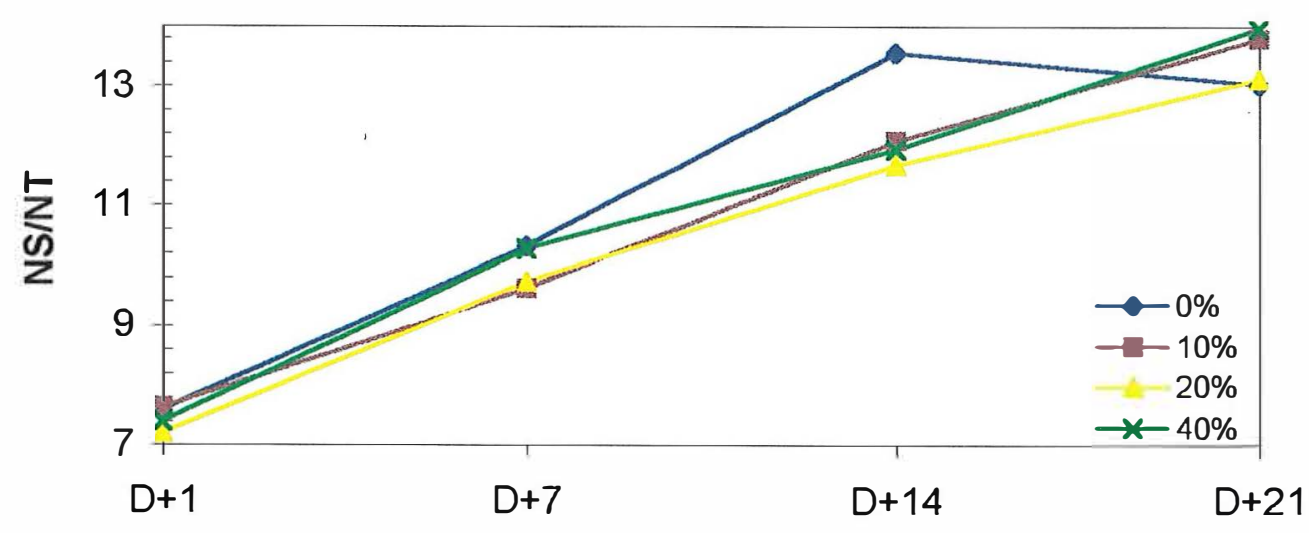

Tempo de Armazenamento

Figura 5 - Evolução dos índices de extensão da proteólise (NS/NT) dos queijos, após 1, 7, 14 e 21 dias da fabricação, com $0,10,20$ e $40 \%$ de leite reconstituído adicionado ao leite in natura.

\subsubsection{Profundidade da proteólise}

A Tabela 10 e a Figura 6 mostram a profundidade da proteólise (relação entre o nitrogênio não protéico e o nitrogênio total) dos queijos obtidos após um dia 
(D+1) e aos 7, 14 e 21 dias após a fabricação dos queijos (D+7, D+14, D+21). Nota-se que ocorre um aumento significativo do teor do nitrogênio não protéico durante a estocagem dos queijos, aumentando, por conseguinte, os índices de profundidade da proteólise dos queijos. Entretanto, entre os tratamentos não houve grandes diferenças; somente diferiu o queijo adicionado de $40 \%$ de leite reconstituído ao leite in natura ao $7^{\circ}$ dia de armazenamento, sendo mais elevado que os demais tratamentos.

Tabela 10. Índices de profundidade da proteólise dos queijos durante o armazenamento.

\begin{tabular}{lccccc}
\hline & \multicolumn{4}{c}{ Leite reconstituído adicionado ao leite in natura (\%) } & \\
\cline { 2 - 5 } $\begin{array}{l}\text { Dias após a } \\
\text { Fabricação }\end{array}$ & 0 & 10 & 20 & 40 & C.V. \\
\hline D+1 & $4,27^{\mathrm{a}}$ & $4,06^{\mathrm{a}}$ & $4,27^{\mathrm{a}}$ & $4,68^{\mathrm{a}}$ & 7,75 \\
D+7 & $5,80^{\mathrm{a}}$ & $5,76^{\mathrm{a}}$ & $6,03^{\mathrm{ab}}$ & $6,54^{\mathrm{b}}$ & 4,09 \\
D+14 & $7,33^{\mathrm{a}}$ & $6,82^{\mathrm{a}}$ & $6,97^{\mathrm{a}}$ & $7,42^{\mathrm{a}}$ & 4,26 \\
D+21 & $8,35^{\mathrm{a}}$ & $7,75^{\mathrm{a}}$ & $7,79^{\mathrm{a}}$ & $8,39^{\mathrm{a}}$ & 4,68 \\
\hline
\end{tabular}

a, b, c Médias com o mesmo expoente, na mesma linha, não são significativamente diferentes $(\mathrm{p}<0,01)$. Médias de quatro fabricações. C.V = Coeficiente de variação.

O Quadro 1 contém dados comparativos de teores de nitrogênio não protéico (NNP) obtidos nesse trabalho e por Wolfschoon-Pombo et al. (1984), observando-se similaridade entre os resultados.

Quadro I - Dados comparativos da evolução média do teor de NNP no queijo Minas Frescal durante o amazenamento.

\begin{tabular}{|l|c|l|c|}
\hline & (0\% leite reconstituído) & & Wolfschoon-Pombo et al. (1984) \\
\hline 1 dia & $0,09-0,13 \%$ & 1 dia & $0,05-0,11 \%$ \\
\hline 7 dias & $0,13-0,15 \%$ & 9 dias & $0,10-0,16 \%$ \\
\hline 14 dias & $0,17-0,18 \%$ & 14 dias & $0,18-0,26 \%$ \\
\hline
\end{tabular}




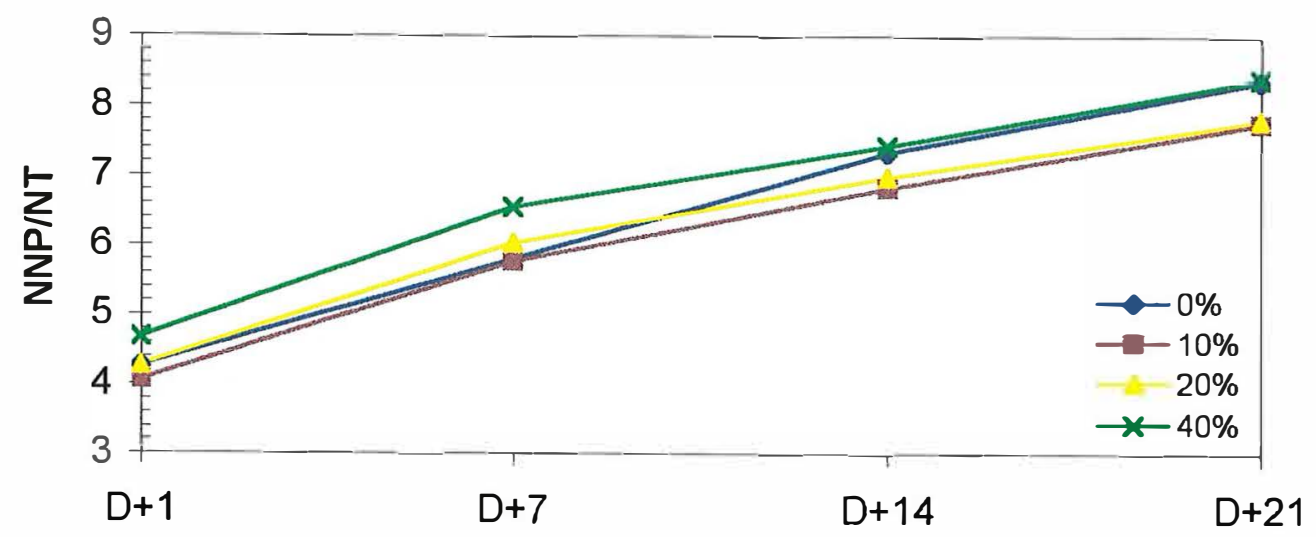

Tempo de Armazenamento

Figura 6 - Evolução dos índices de profundidade da proteólise (NNP/NT) dos queijos, após 1, 7, 14 e 21 dias da fabricação, com $0, \quad 10,20$ e $40 \%$ de leite reconstituído adicionado ao leite in natura.

O acúmulo de nitrogênio solúvel é devido principalmente à ação proteolítica que tem o coalho residual sobre as caseínas, especialmente as frações alfa e beta; por outro lado, o nitrogênio não protéico aumenta graças à ação de enzimas (exopeptidases) dos microrganismos presentes, sobre os peptídeos formados pela hidrólise da caseína pelo coalho (Choisy et al., 1986). De modo geral, segundo Wolfschoon-Pombo et al. (1984), o coalho influencia a extensão da proteólise enquanto que as bactérias, através de suas aminopeptidases, carboxipeptidases, dipeptidases, determinam a profundidade da proteólise. A atividade proteolítica, incluindo aquela da protease natural do leite, quantifica-se através dos índices de proteólise mostrados na Tabela 9 e 10.

\subsection{5 Índice de tirosina}

A Tabela 11 e a Figura 7 apresentam os teores médios do aminoácido tirosina determinados através de espectrofotômetro. Os valores foram significativamente diferentes $(p>0,01)$ somente para aqueles obtidos após um dia $(D+1)$ da fabricação dos 
queijos, sendo que o tratamento com adição de $40 \%$ de leite reconstituído apresentou teores médios de tirosina inferiores aos demais. Os teores de tirosina, como esperado, aumentaram gradativamente ao longo do armazenamento, sem que houvesse diferenças significativas entre os tratamentos após a $2^{\underline{a}}, 3^{\underline{a}}$ e $4^{\underline{a}}$ semanas. No entanto, os valores obtidos do tratamento adicionado de $40 \%$ de leite reconstituído ao leite in natura, apresentaram tendência a serem inferiores aos demais tratamentos nesse mesmo período $(\mathrm{D}+7, \mathrm{D}+14$ e $\mathrm{D}+21)$.

Tabela 11. Teores médios de tirosina, $(\mathrm{mg} / 100 \mathrm{~g})$ dos queijos durante o armazenamento.

\begin{tabular}{cccccc}
\hline & \multicolumn{4}{c}{ Leite reconstituído adicionado ao leite in natura (\%) } & \\
\cline { 2 - 5 } $\begin{array}{c}\text { Dias após a } \\
\text { Fabricação }\end{array}$ & 0 & 10 & 20 & 40 & C.V. \\
\cline { 1 - 5 } D+1 & $35,49^{\mathrm{a}}$ & $31,73^{\mathrm{ab}}$ & $29,54^{\mathrm{ab}}$ & $21,07^{\mathrm{b}}$ & 13,99 \\
D+7 & $48,89^{\mathrm{a}}$ & $45,72^{\mathrm{a}}$ & $37,21^{\mathrm{a}}$ & $34,31^{\mathrm{a}}$ & 14,18 \\
D+14 & $56,48^{\mathrm{a}}$ & $53,86^{\mathrm{a}}$ & $48,79^{\mathrm{a}}$ & $43,86^{\mathrm{a}}$ & 8,38 \\
D+21 & $61,48^{\mathrm{a}}$ & $64,57^{\mathrm{a}}$ & $60,18^{\mathrm{a}}$ & $59,46^{\mathrm{a}}$ & 7,37 \\
\hline
\end{tabular}

a, b, c Médias com o mesmo expoente, na mesma linha, não são significativamente diferentes $(\mathrm{p}<0,01)$. Médias de quatro fabricações. $\mathrm{C} . \mathrm{V}=$ Coeficiente de variação.

Alguns pesquisadores afirmam que a degradação protéica em queijos elaborados utilizando-se leite em pó, tende a ser mais lenta do que em queijos fabricados com leite in natura (Gilles et al., 1979; Czulak \& Hammond, 1974; El Ghandour et al., 1983b). Omar \& Buchein (1983b) encontraram teores de aminoácidos livres em queijos Gouda fabricados com leite reconstituído, significativamente inferiores a do queijo controle. Entretanto, Abd El Salan et al. (1983) não encontraram diferenças significativas nos teores de nitrogênio solúvel e tirosina em queijo branco condimentado, quando comparado ao queijo controle. 


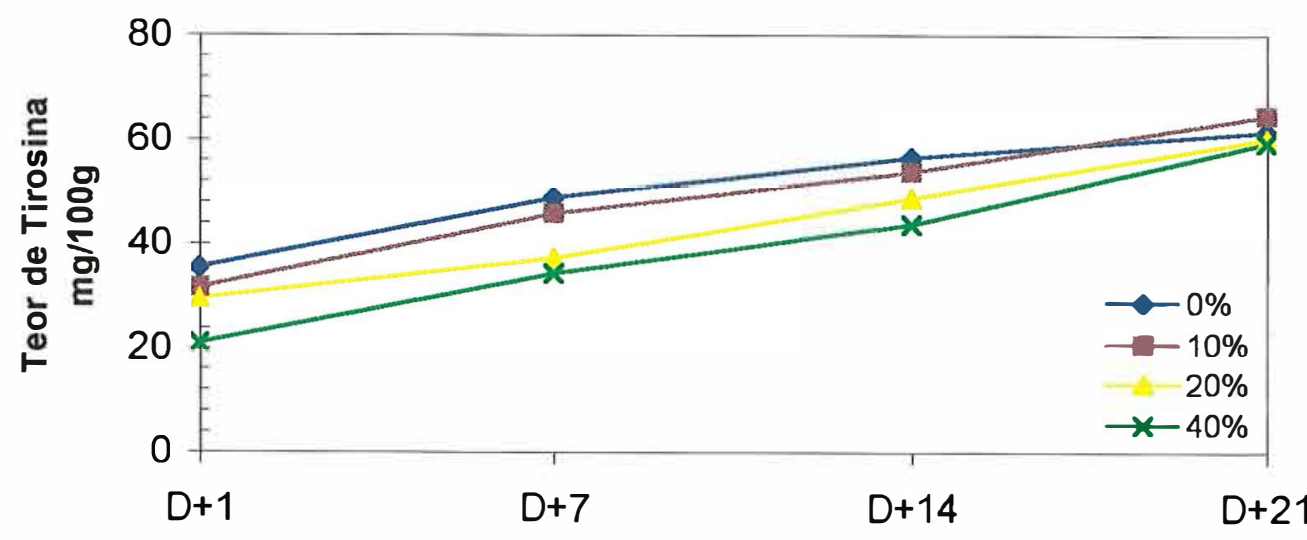

Tempo de Armazenamento

Figura 7 - Evolução dos índices de tirosina dos queijos, após 1, 7, 14 e 21 dias da fabricação, com $0,10,20$ e $40 \%$ de leite reconstituído adicionado ao leite in natura.

\subsection{Avaliação sensorial}

A análise sensorial realizada neste trabalho teve por finalidade avaliar se os queijos elaborados com leite reconstituído adicionado ao leite in natura possuíam aceitabilidade semelhante a queijos tradicionais, através da escala hedônica não estruturada de $9 \mathrm{~cm}$.

Através da Figura 8, observou-se que as maiores freqüências de resposta para os queijos elaborados com 10 e $20 \%$ de leite reconstituído foram em torno de 7,5; com $40 \%$, foi em torno de 6 .

A Tabela 12 contém as médias de notas dadas aos queijos na avaliação sensorial, dois dias após a fabricação dos queijos. De acordo com os resultados, todos os queijos obtiveram aceitação semelhante, não diferenciado estatisticamente $(p<0,01)$. No entanto, houve uma tendência à preferência para o queijo fabricado com $20 \%$ de leite reconstituído adicionado ao leite in natura. 
Tabela 12. Médias de notas dadas aos queijos na análise sensorial em $\mathrm{D}+2$ através de escala hedônica não estruturada.

\begin{tabular}{lccccc}
\hline & \multicolumn{2}{c}{$\%$ de leite reconstituído adicionado ao leite in natura } \\
\cline { 2 - 5 } Atributo & $0 \%$ & $10 \%$ & $20 \%$ & $40 \%$ & C.V. \\
\hline Notas & $5,88^{\mathrm{a}}$ & $6,17^{\mathrm{a}}$ & $6,67^{\mathrm{a}}$ & $5,72^{\mathrm{a}}$ & 34,41 \\
\hline
\end{tabular}

* Médias de 50 notas

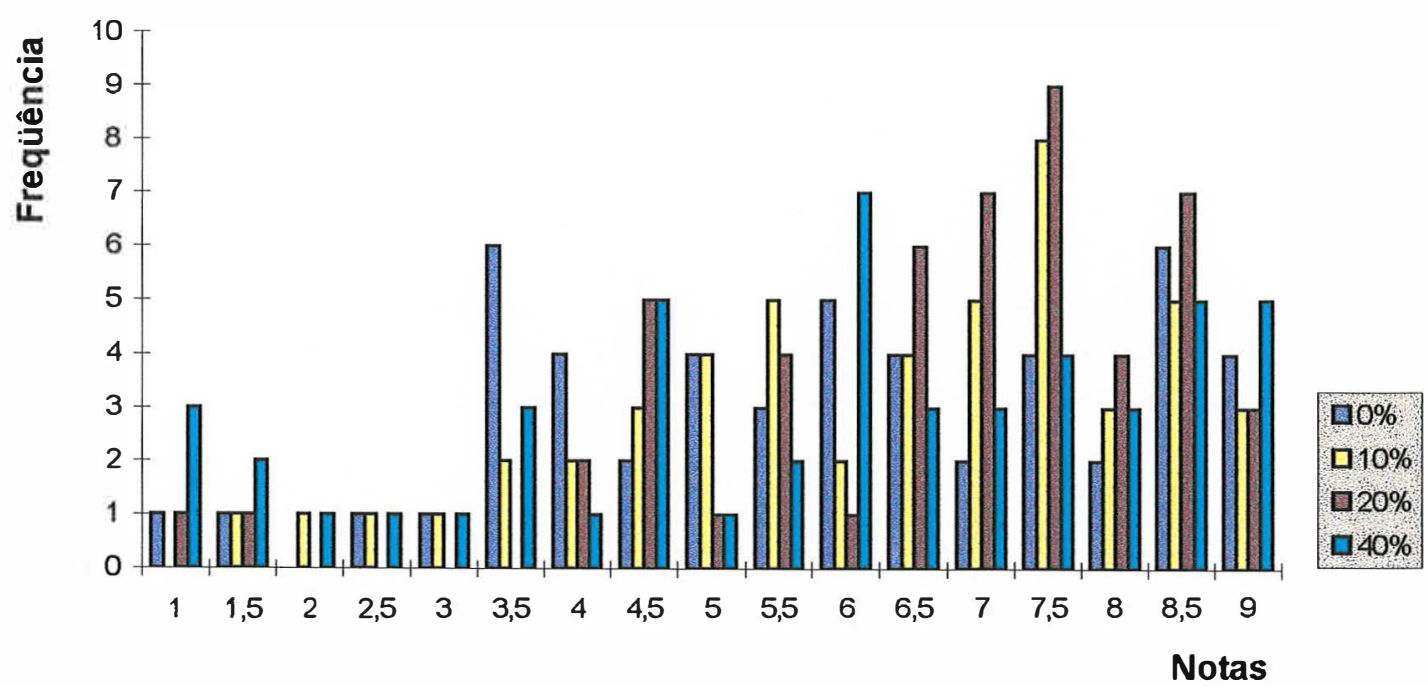

Figura 8 - Freqüência de respostas do teste de aceitação (escala hedônica) de queijos elaborados com adição de 0, 10, 20 e $40 \%$ de leite reconstituído adicionado ao leite in natura. 


\section{CONCLUSÕES}

É possível a fabricação do queijo Minas Frescal com adição de até $40 \%$ de leite reconstituído ao leite in natura, pois não afetou as características físicoquímicas, quanto ao $\mathrm{pH}$, acidez titulável, teor de sal e atividade de água, além da aceitabilidade e durabilidade dos queijos obtidos.

Ocorreu apenas o inconveniente do tempo de agitação da coalhada ser superior para os queijos fabricados com $20 \%$ e $40 \%$ de leite reconstituído adicionado ao leite in natura para que se atingisse pontos de massa similares. Mesmo assim, a umidade dos queijos com $40 \%$ de leite reconstituído adicionado ao leite in natura foi superior aos demais queijos. Por outro lado, verificou-se uma tendência no aumento de rendimento em gramas de sólidos totais por litro de leite com o aumento da quantidade de leite reconstituído. 


\section{REFERÊNCIAS BIBLIOGRÁFICAS}

ABD EL SALAM, M.H.; EL SHIBINY, S.; MEHANNA, N. Proteolysis in pickled soft cheese from recombined milk concentrated by ultrafiltration as affected by rennets and starter cultures used. Egyptian Journal of Dairy Science. v.2, n.11, p.291298, 1983.

AL-TAHIRI, R. Recombined and reconstituted milk products. New Zealand Journal of Dairy Science and Technology. n.22, p.1-23, 1987.

AMERICAN DRY MILK INSTITUTE. Standards for grades of dry milk including methods of analysis. Chicago, 1971. p.1v. (Bulletin 916).

ASSOCIATION OF OFFICIAL ANALYTICAL CHEMISTS. Official methods of analysis. 15 ed. Washington, 1995. 109p.

BANKS, J.M.; BANKS, W.; MUIR, D.D.; WILSON, A.G. Cheese yield: composition does matter. Dairy Industrial International. v.46, n.5, p.15-22, May. 1981.

BARBANO, D.M. Mozzarella cheese yield: factors to consider. In: THE CHEESE SHOW, La Crosse, 1996. Anais. La Crosse: Wisconsin Cheese Makers Association, 1996. p.29-39.

BRASIL. Secretaria Nacional de Defesa Agropecuária. Laboratório Nacional de Referência Animal. Métodos analíticos oficiais para controle de produtos de origem animal e seus ingredientes. II. Métodos físicos e químicos. Brasília, 1981, p.1v.

BRITISH STANDARD METHODS FOR ANALYSIS OF DRIED MILK AND DRIED MILK PRODUCTS. Assessment of the heat class of dried milk. Section 6.1 heat number method. British Standards Institution. 1983. Part 6. 
CASAGRANDE, H.R.; WOLFSCHOON-POMBO, A.F. Fermentação da lactose no queijo Minas Frescal. Revista do Instituto de Laticínios “Cândido Tostes”, v.43, n.258, p.38, 1988.

CHERREY, G. Reconstituted milk in the manufacture of cheese. La Technique Laitière.n.912, p.37-41; Out. 1977.

CHERREY, G.; LABLÉE, J. Recombined cheese. B. Various cheese types. Bulletin International Dairy Federation, n.116, p.36-38, 1979.

CHERREY, G.; LABLÉE, J. The use of recombined or reconstituted milk. . IN: ECK, A. Cheesemaking - science and tecnology. New York: Lavoisier Publ., 1986. cap.4, p.402-412.

CHOISY, C.; DESMAZEAUD, M.; GRIPON, J.C.; LAMBERET, G.; LENOIR, J. Microbiologycal and biochemical aspects of ripening. IN: ECK, A. Cheesemaking - science and tecnology. New York: Lavoisier Publi., 1986. cap.4, p.62-100.

COVARRUBIAS, M.P.; ISRAEL, L . E.; VALDENEGRO, V. Desnaturação de proteínas do soro do leite por processos térmicos - UHT. Densitometria em géis de poliacrilamida. Revista do Instituto de Laticínios “Cândido Tostes”, v.43, n.258, p.15-20, 1988.

CZULAK, J.; HAMMOND, L.A. Manufacture of cheese from recombined milk. In: XIX International Dairy Congress. p.781-782, 1974.

DALGLEISH, D.G. Milk Proteins - Chemistry and physics. In: FOX, P.F.; CONDON, J.J. Food Proteins. London: Applied Science Publ., 1982. cap. 8, p.155-178.

DE WIT, J.N. Structure and funtional behavior of whey proteins. Netherland Milk Dairy Journal. v.1, n.35, p.47-64, 1981.

DOZET, N.; STANISIC, M.; BIJELJAC, S. Study of utilization of reconstituted milk in cheese production. Mljekarstvo. v.12, n.33, p.369-376, 1983. 
EL GHANDOUR, M.A; HAGRASS, A.E.A.; HAMMAD, Y. A ; HOFI, A.A. Production of Ras cheese from recombined milk. I. Curd characteristics. Egyptian Journal of Dairy Science. v.1, n.11, p.77-85, 1983a.

EL GHANDOUR, M.A; HAGRASS, A.E.A.; HAMMAD, Y. A ; HOFI, A.A. Production of Ras cheese from recombined milk. II. Effect of some salts. Egyptian Journal of Dairy Science. v.1, n.11, p.87-94, 1983b.

EL SODA, M. Recent developments in accelerated cheese ripening. Journal of Dairy Science. v.74, n.7, p.2317-2335, 1991.

EL SODA, M.; EZZAT, N.; SALAM, A.; KHAMIS, A. Accelerated ripening of cheese made from recombined milk. International Dairy Federation. Special Issue. n.9001, p.290-297, 1988.

EL ZAYAT, A .I.; OMAR, M.M. The growth of Penicillium roqueforti in Blue cheese made from recombined milk: scanning electron microscopy study. Deutsche Lebensmittel Rundschau. v.5, n.81, p.142-146, 1985.

EMMONS, D.B.; ERNSTROM, C.A.; LACROIX, C.; VERRET, P. Predictive formulas for yield of cheese from composition of milk: a review. Journal of Dairy Science. v.73, n.6, p.1356-1394, 1990.

ESTEBAN, M.A.; MARCOS, A. Equations for calculation of water activity in cheese from its chimical composition: a review. Food Chemistry, v.35, p.179-186, 1990.

FOLEGATTI, M.I. Avaliação do uso de quimosina produzida por Aspergillus niger na fabricação de queijo tipo prato. Campinas, 1994. 65p. Dissertação (Mestrado) Faculdade de Engenharia de Alimentos, Universidade Estadual de Campinas.

FOX, P.F. Proteolysis during cheese manufacture and ripening. Journal of Dairy Science. n.72, p.1379-1400, 1989.

FOX, P.F. Rennets and their action in chese manufacture and ripening. Biotechnology and Applied Biochemistry. n.10, p.522-535, 1988.

FURTADO, M.M. A arte e a ciência do queijo. 2.ed. São Paulo: Globo, 1990. 
FURTADO, M.M. Métodos para a padronização da gordura no extrato seco do queijo. Revista do Instituto de Laticínios “Cândido Tostes”. v.30, n.182, nov/dez. 1975.

FURTADO, M.M.; LOURENÇO NETO, J.P. de M. Chymogen: primeiro coalho genético no Brasil. Informativo Ha-la Biotec. n.8; p.2; abr. 1992.

FURTADO, M.M.; LOURENÇO NETO, J.P. de M. Coalho. Um fator determinante da qualidade e rendimento da fabricação. Informativo Ha-la Biotec. n.1; p.2; jan.1991a.

FURTADO, M.M.; LOURENÇO NETO, J.P. de M. O rendimento da fabricação de queijos. Informativo Há-la Biotec. n.4; p.2; jul.1991b.

FURTADO, M.M.; LOURENÇO NETO, J.P. de M. Tecnologia de queijos. Manual técnico para a produção industrial de queijos. São Paulo: Dipemar, 1994. 112p.

FURTADO, M.M.; PARTRIDGE, J.A. Caracterization of nitrogen fractions during ripening of a soft cheese made from ultrafiltration retentates. Journal of Dairy Science, v.71, p.2877, 1988.

FURTADO, M.M.; SOUZA, H.M.; MUNCK, A.V. A fabricação do queijo Minas Fréscal sem o emprego de culturas lácticas. Revista do Instituto de Laticínios “Cândido Tostes”, v.35, n.207, p.15-21. jan/fev. 1980.

FURTADO, M.M.; WOLFSCHOON-POMBO, A.F. Fabricação de queijo Prato e Minas: estudo do rendimento. Parte I - Determinação das cifras de transição. Revista do Instituto de Laticínios “Cândido Tostes”. v.34, n.205, set/out. 1979a.

FURTADO, M.M.; WOLFSCHOON-POMBO, A.F. Fabricação de queijo Prato e Minas: estudo do rendimento. Parte II - Previsão da gordura no extrato seco. Revista do Instituto de Laticínios “Cândido Tostes”. v.34, n.206, nov/dez. 1979b.

GALAN, V.B. Boletim do Leite. Centro de estudos avançados em economia aplicada Boletim CEPEA. v.4, n.39, jun. 1997. 
GALLINA, D.A ; BRANDÃO, S.C.C. Queijos - melhorar o rendimento significa mais lucro. Indústria de Laticínios. v.1, n.1, p.45-49, abr. 1996.

GEUS, D.C. de Cooperativa: profissionalismo e parcerias para o novo mercado. Indústria de Laticínios. v.1, n.6, p.5,6-8, nov/dez. 1996.

GILLES, J.; LAWRENCE, R.C. Manufacture of cheese and other fermented products from recombined milk. New Zealand Journal of Dairy Science and Technology. n.15, p.1-12, 1981.

GILLES, J.; LAWRENCE, R.C. Manufacture of cheese and other fermented products from recombined milk. Bulletin International Dairy Federation. n.142, p.111-117, 1982.

GILLES, J.; LAWRENCE, R.C.; CZULAK, J.; CONOCHIE, J. HAMMOND, L.A. Recombined cheese. A. Cheddar, Edan and Cottage cheese. Bulletin International Dairy Federation. n.116, p.33-35, 1979.

GRAPPIN, R.; RANK, T.C.; OLSON, N.F. Primary Proteolysis of cheese proteins during ripening. Journal of Dairy Science. v.68, n.3, p.531-540, 1985.

GRIPON, J.C.; DESMAZEAUD, M.J.; LE BARS, D.; BERGERE, J.L. Étude du rôle des micro-organismes et des enzymes au cours de la maturation des fromages. II Influence de la presure commerciale. Le Lait. v.55, n.548, p.502-515, 1975.

GUINEE, T.P.; FOX, P.F. Salt in cheese: physical, chemical and biologycal aspects. In: FOX, P.F. (ed.). Cheese: chemistry, physics and microbiology, New York, Elsevier Applied Publ. Science. 1987, v.1, p.31-35, 1984.

GUINEE, T.P.; WILKINSON, M.G. Rennet coagulation and coagulants in cheese manufacture. Journal of the Society of Dairy Technology. v.45, n.4, p.94-104, Nov. 1992.

HAGRASS, A.E.A.; EL GHANDOUR, M.A.; HAMMAD, Y.A. Production of Ras cheese from recombined milk. III. Effect of some ripening agents. Egyptian Journal of Dairy Science. v.2, n.11, p.271-279, 1983. 
HAMMOMD, L.A. Fermented products from recombined milk. Specialist Courses for the Food Industry. Seminar on recombined dairy products. n.3 p.58-64, 1972.

HARDY, J. Water activity and salting of cheese. In: ECK, A. Cheesemaking - science and tecnology. New York: Lavoisier Publi., 1986. cap.3, p.37-61.

HARLAND, H.A.; ASHWORTH, U.S. A rapid method for estimation of whey proteins as an indication of baking quality of non fat dry-milk solids. Food Research, v. 12, p.247-251, 1947.

HASSAN, H.N.; EL DEEB,S.A. Repercussions of aging recombined milk or adding salts to it to produce Ras cheese. Alexandria Science Exchenge. v.4, n.7, p. 435449, 1986.

HILL, A.R.; BULLOCK, D.H.; IRVINE, D.M. Manufacturing parameters of Queso Blanco made from milk and recombined milk. Canadian Institute of Food Science and Technology Journal. v. , n.15, p.47-53, 1982.

INTERNATIONAL DAIRY FEDERATION. Determination of the total nitrogen content of milk by Kjeldahl method. FIL-IDF, n.20, p.1-3, 1962.

JANA, H.A.; THAKAR, P.N. Recombined milk cheese - a review. The Australian Journal of Dairy Technology. v.51, p.33-43, Apr. 1996.

LABLÉE, J. Manufacture of cheese from recombined milk. Revue Laitiere Francaise. n.373, p.17-21, 1979.

LANARA (Laboratório Nacional de Referência Animal) Métodos analíticos oficiais para controle de produtos de origem animal e seus ingredientes. Brasília, 2, $1981.1 \mathrm{v}$.

LELIEVRE, J.; SHAKER, R.R.; TAYLOR, M.W. The role of homogenization in the manufacture of Halloumi and Mozzarella cheese from recombined milk. Journal of the Society of Dairy Technology. v.1, n.43, p.21-24, 1990. 
MARCOS, A.; ALCALÁ, M.; LEÓN, F.; FERNÁNDEZ-SALGUEIRO, J.; ESTEBAN, M.A. Water activity and chemical composition of cheese. Indian Journal of Dairy Science. v.64, n.4, p.622-626, 1981.

MASHALY, R.I.; ABOU DONIA, S.A.; EL SODA, M. Utilization of dried milk for Domiati cheese. Indian Journal of Dairy Science. v.1, n.36, p.93-95, 1983.

MEHANNA, N.M.; EL SHIBINY, S.; ABD EL SALAM, M.H. Proteolysis of soft cheese from recombined milk, and made by ultrafiltration techniques. Egyptian Journal of Dairy Science. v.1, n.11, p.167-171, 1983.

MIETTON, B. Use of conventional process for the manufacture of recombined cheese. International Dairy Federation. Special Issue. n. 9001, p.275-278, 1988.

MORI, E.E.M. Métodos sensoriais e físicos para a avaliação de alimentos e bebidas: princípios e aplicação. Campinas: ITAL, 1982. 50p.

MUNCK, A.V.; SOUZA, H.M. Estudo conclusivo a respeito da fabricação do queijo Minas Frescal por diferentes processos. Revista do Instituto de Laticínios “Cândido Tostes", v.35, n.208, p.13-16. mar/abr. 1980.

NEWLANDER, J.A.; ATHERTON, H.V. Babcock, Gerber, Monjonier tests for fat. In:----- The chemistry and testing of dairy products. Milwaukee: Olsen Publ., 1964, cap.4, p.67-114.

OLIVEIRA, A J.; CARUSO, J.G.B. Leite - Obtenção e qualidade do produto fluido e derivados. Piracicaba: FEALQ, 1996. 80p.

OMAR, M.M.; BUCHHEIM, W. Composition and microstructure of soft brine cheese made from instant whole milk powder. Food Microstructure. v.1, n.2, p.43-50, 1983a.

OMAR, M.M.; BUCHHEIM, W. Protein breakdown in Gouda type cheese made from recombined milk. Egyptian Journal of Dairy Science. v.2, n.11, p.281-290, $1983 b$. 
PARNELL-CLUNIES, E.M.; IRVINE, D.M.; BULLOCK, D.H. Heat treatment and homogenization of milk for Queso Blanco (Latin American white cheese) manufactured. Canadian Institute of Food Science and Tecnology Journal. v.18, n.2, p.133-136, 1985.

PARRY JR., R.M. Milk coagulation and protein denaturation. In: WEBB, B.H.; JOHNSON, A .H.; ALFORD, J.A . Fundamentals of dairy chemistry. 2.ed. Connecticut: The Avi, 1974. cap.11, p.603-661.

PEREIRA, J.F. Análises bromatológicas. Juiz de Fora: Universidade Federal de Juiz de Fora, $1975,97 \mathrm{p}$.

PIMENTEL-GOMES, F. Curso de estatística experimental. São Paulo: Nobel, 1985. 466 .

POINTURIER, H. Fresh cheese manufactured from recombined cream. Bulletin International Dairy Federation. n.142, p.126, 1982.

PRIMO, W.M. Entressafra no Brasil: meio século de drama. Indústria de Laticínios. v.1, n.2, jun. 1996a.

PRIMO, W.M. Leite: Mercosul em busca da auto-suficiência. Indústria de Laticínios. v.1, n.4, set. $1996 \mathrm{~b}$.

RABIE, A.M.; FARAHAT, S.M.; FARAG, A.A. Ripening changes and quality of recombined milk blue cheese as affected by mould strain and salting method. Food Chemistry. v.4, n.29, p.241-255, 1988.

RANAS OLIVEROS, M.C.; DULAY, T.A. Studies on cheese manufactured from partly reconstituted skim milk powder. I. The quality of soft cheese prepared from cow's milk with two levels of reconstitued skim milk powder. Philippine Journal of Veterinary and Animal Sciences. v.8, n.3/4, p.77-82, 1982.

ROSSI, D.A. Utilização dos coalhos microbiano, bovino e genético na elaboração do queijo Minas Frescal. Lavras, 1997. 77p. Dissertação (Mestrado) - Universidade Federal de Lavras. 
RÓTULOS já contam com algumas normas. Indústria de Laticínios. v.1, n.4, p.26;28, 1996.

SAITO, T.; SCHIFTAN, T.Z. Estudos da composição de queijo Minas Frescal, fabricado na cidade de São Paulo. Revista do Instituto de Laticínios "Cândido Tostes", v.33, n.199, p.29-37. set/out. 1978.

SANDERSON, W.B. Dairy products. Bulletin International Dairy Federation. n.116, p.40-42, 1979.

SIAPANTAS, L Effect of milk reconstitution, ultrafiltration and cheese processing in the manufacturing cost of Feta cheese. In: BIENNIAL MARSCHALL INTERNATIONAL CHEESE CONFERENCE, 1., 1981. Proceedings. p.617-626.

TEIXEIRA JR., S. Queijos - Conhecer o mercado para conquistá-lo. Indústria de Laticínios. v.1, n.4, p.50, 1996.

THONPSON, M.P. Mozzarella cheese made with non fat dried milk. Food Engineering International. n.3, p.25, 1978.

VAKALERIS, D.G.; PRICE, W.V. A rapid spectrophotometric method for measuring cheese ripening. Journal of Dairy Science, v.42, p.264-276, 1959.

VAN DEN BERG, M.G.; VAN DEN BERG, G.; VAN BOEKEL, M.A.J.S. Mass transfer process invoved in Gouda cheese manufacture, in relation to casein and yield. Netherlands Milk and Dairy Journal. n.50, p.501-540, 1996.

VANDEWEGHE, J.; MAUBOIS, J. The yield of cheese - Predetermination and measurement. In: ECK, A. Cheesemaking - science and tecnology. New York: Lavoisier Publi., 1986. cap.23, p.469-477.

VIEIRA, S.D.A.; NEVES, B. dos S. Adição de leite reconstituído na fabricação de queijo tipo prato. Revista do Instituto de Laticínios "Cândido Tostes", v.35, n.212, p.19-25. nov/dez. 1980.

VISSER, S. Proteolytic enzymes and their action on milk proteins - A review. Netherlands Milk and Dairy Journal, v.35, n.1, p.65-83, 1981. 
WHITE, C.H.; RYAN, J.M. Defining optimal conditions for making Cottage cheese from reconstituted milk powder. Journal of Food Protection. v.8, n.46, p.686689,692, 1983.

WOLFSCHOON-POMBO, A .F.; FERNANDES, R.M.; GRANZINOLLI, G.G.M. Efeitos da pasteurização HTST e da fervura doméstica sobre a proteína do leite. Revista do Instituto de Laticínios “Cândido Tostes”, v.37, n.223, p.3-7, set/out. 1982.

WOLFSCHOON-POMBO, A. L. Índice de proteólise em alguns queijos brasileiros. Boletim do Leite e seus Derivados, v.56, n.661, p.1-8, nov. 1983.

WOLFSCHOON-POMBO, A. L.; LIMA, A. de Extensão e profundidade da proteólise em queijo Minas Frescal. Revista do Instituto de Laticínios "Cândido Tostes", v.44, n.261-266, p.50-54, 1989.

WOLFSCHOON-POMBO, A.F.; CASAGRANDE, H.R.; LORENÇO-NETO, J.P.M.; MUNCK, A.V. Alterações no queijo Minas Frescal durante o período de armazenamento. Revista do Instituto de Laticínios "Cândido Tostes", v.39, n.233, p.3-9, 1984.

WOLFSCHOON-POMBO, A.F.; FURTADO, M.M.; MUNCK, A.V. Estudo da fabricação do queijo Minas Frescal com ácido lático em substituição ao fermento lático. In: CONGRESSO NACIONAL DE LATICÍNIOS, 5., Juiz de Fora, 1978. Anais. Juiz de Fora: EPAMG. Instituto de Laticínios "Cândido Tostes", 1978. p.161-182.

XAVIER, AJ. Leite: Atividade rentável à espera da produtividade. Leite e Derivados. V Catálogo Brasileiro de Produtos e Serviços. p.80, 1997.

ZURAW, J.; QUIST, K.B.; MADSEN, J.S.; BRAUN, H.; JENSEN, G.K. Manufacture of Danbo cheese from reconstitued low heat skim milk powder and fresh cream. Beretning-fra-Statens-Majeriforsog. n.265, p.1-27, 1985. 